HNF-EP-0835-6

Revision 0

\title{
Statement of Work for Services Provided by the Waste Sampling and Characterization Facility for the Environmental Compliance Program During Calendar Year 2000
}

Prepared for the U.S. Department of Energy

Assistant Secretary for Environmental Management

Project Hanford Management Contractor for the

U.S. Department of Energy under Contract DE-AC06-96RL13200

Fluor Hanford

P.O. Box 1000

Richland, Washington 
HNF-EP-0835-6

Revision 0

\title{
Statement of Work for Services
}

\section{Provided by the Waste Sampling and} Characterization Facility for the Environmental Compliance Program

\section{During Calendar Year 2000}

\author{
D. J. Rokkan
}

Flour Hanford

Date Published

June $\mathbf{2 0 0 0}$

Prepared for the U.S. Department of Energy

Assistant Secretary for Environmental Management

Project Hanford Management Contractor for the

U.S. Department of Energy under Contract DE-AC06-96RL 13200

Fluor Hanford

P.O. Box 1000

Richland, Washington

$\frac{\text { Chis is idengfiand }}{\text { Release Approval }} \frac{6 / 27 f 00}{\text { Date }}$ 
TRADEMARK DISCLAIMER

Reference herein to any specific commercial product, process,

or service by trade name, trademark, manufacturer, or

otherwise, does not necessarily constitute or imply its

endorsement, recommendation, or favoring by the United

States Government or any agency thereof or its contractors or subcontractors.

This report has been reproduced from the best available copy. 
HNF-EP-0835-6

Document Title: STATEMENT OF WORK FOR SERVICES PROVIDED BY THE WASTE SAMPLING AND CHARACTERIZATION FACILITY FOR THE ENVIRONMENTAL COMPLIANCE PROGRAM DURING CALENDAR YEAR 2000

Prepared by:

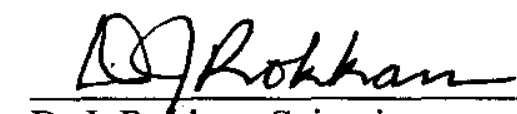

D. J. Rokkan, Scientist

Monitoring \& Reporting

Fluor Hanford Environmental Services

Approved by:

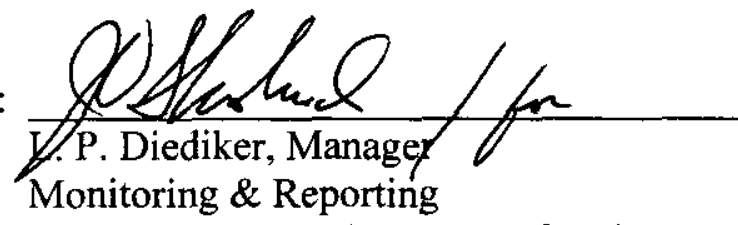

Fluor Hanford Environmental Services

Approved by:

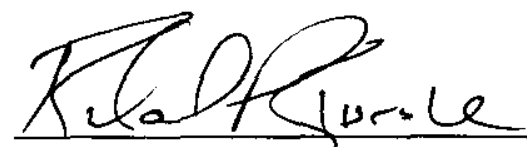

R. H. Gurske, Manager

Fluor Hanford Environmental Services

Approved by:

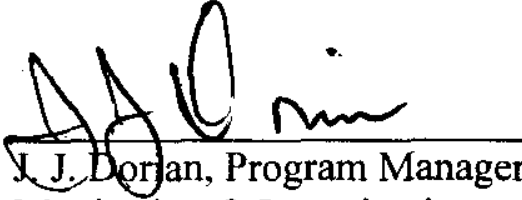

Monitoring \& Investigations

Waste Marfagement Technical Services

Approved by:

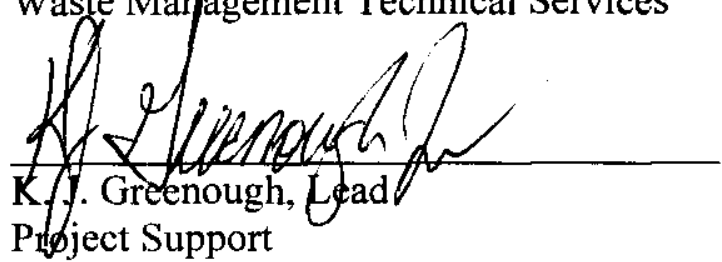

Waste Sampling and Characterization Facility

Fluor Hanford Analytical Services

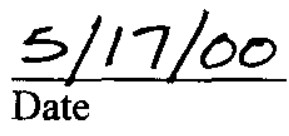

$\frac{5-17-00}{\text { Date }}$

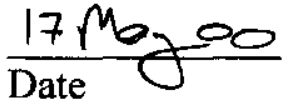

$5 / 18 / 00$

Date

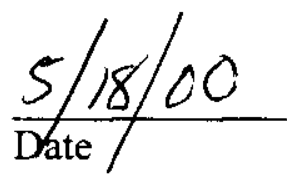


HNF-EP-0835-6

This page intentionally left blank. 
HNF-EP-0835-6

\section{TABLE OF CONTENTS}

1.0 SCOPE OF SERVICES

2.0 REGULATORY REPORTING REQUIREMENTS .........................................................

2.1. RADIONUCLIDE AIR EMISSIONS REPORT FOR THE CLEAN AIR ACT .............. 2

2.2. ENVIRONMENTAL RELEASES REPORT …….................................................. 2

2.3. HANFORD SITE ENVIRONMENTAL REPORT …......................................... 2

2.4. EFFLUENT INFORMATION SYSTEM-ONSITE DISCHARGE INFORMATION SYSTEM REPORT

2

2.5. HANFORD SITE NEAR-FACILITY ENVIRONMENTAL MONITORING ANNUAL REPORT.

3.0 WSCF SERVICES AND DATA QUALITY OBJECTIVES .............................................. 3

3.1. SAMPLE AND ANALYSIS REQUIREMENTS ……............................................. 3

3.2. COMPOSITE SAMPLE REPORTING REQUIREMENTS …................................. 3

3.3. YEAR-END DATA REPORTING DUE DATES …................................................. 3

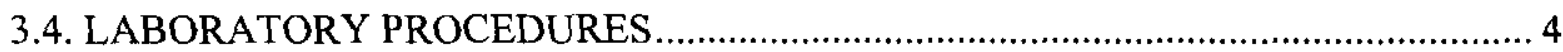

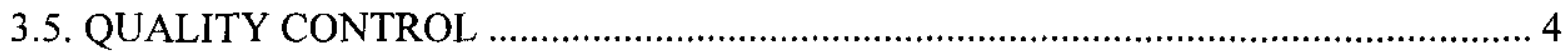

3.6. RETENTION OF AND ACCESS TO RAW DATA AND RESULTS ......................... 6

3.7. ANALYTICAL ERROR \& MINIMUM DETECTABLE CONCENTRATION ............. 6

3.8. ROUTINE ELECTRONIC TRANSFER OF ANALYTICAL DATA ............................6

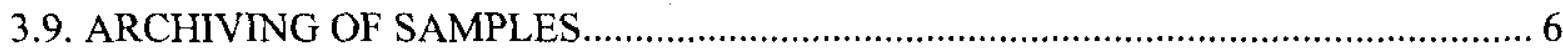

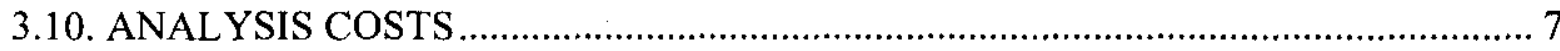

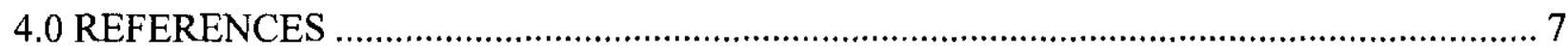

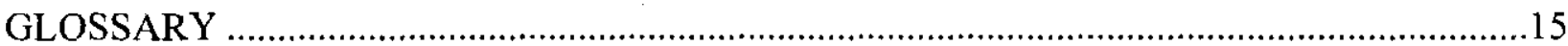

APPENDIX 
HNF-EP-0835-6

\section{LIST OF TABLES}

1 Air Emission and Ambient Air Sample Analysis Criteria for the Waste Sampling and Characterization Facility

2 Groundwater Monitoring and Liquid Effluent Sample Analysis Criteria for the Waste Sampling and Characterization Facility

3 Pond Vegetation and Sediment Sample Analysis Criteria for the Waste Sampling and Characterization Facility

4 Additional Services Factored into the Waste Sampling and Characterization Facility Sample Analysis Prices for the Environmental Compliance Program

A-1 Airborne Effluent Samples and Analyses for CY 2000 APP-2

A-2 Liquid Effluent Samples and Analyses for CY 2000 APP-7

A-3 Near-Facility Monitoring Air Samples and Analyses for CY 2000 APP-8

A-4 Near-Facility Monitoring Soil Samples and Analyses for CY 2000 APP-12

A-5 Near-Facility Monitoring Vegetation Samples and Analyses for CY 2000 APP-16 
HNF-EP-0835-6

\section{STATEMENT OF WORK FOR SERVICES PROVIDED BY THE WASTE SAMPLING AND CHARACTERIZATION FACILITY FOR THE ENVIRONMENTAL COMPLIANCE PROGRAM DURING CALENDAR YEAR 2000}

\subsection{SCOPE OF SERVICES}

This document defines analytical services the Waste Sampling and Characterization Facility (WSCF) shall provide the Environmental Compliance Program (ECP) throughout calendar year (CY) 2000. Two organizations within ECP are responsible for monitoring liquid and gaseous effluents and the environment immediately around facilities that contain or may contain radioactive and hazardous materials. Monitoring \& Reporting (M\&R), of Fluor Hanford Environmental Services, is responsible for effluent monitoring data, and Environmental Monitoring \& Investigations (EMI), of Waste Management Technical Services, Inc., for nearfacility environmental monitoring data. These organizations serve numerous projects, some of which are managed by other companies such as CH2M HILL and Bechtel Hanford, Inc. Monitoring data are collected and evaluated to determine their state of compliance with applicable federal and state regulations and permits, and then published in various reports. M\&R is also responsible for issuing this annual statement of work.

The Appendix identifies CY 2000 samples M\&R and EMI plan to submit to WSCF for analysis. Analysis of effluent (i.e., liquid discharges and air emissions) and environmental (i.e., air, liquid, animal, and vegetative) samples is required using standard laboratory procedures, in accordance with regulatory and control requirements cited in NESHAP Quality Assurance Project Plan for Radioactive Air Emissions Data (HNF-EP-0528-3), Near-Facility Environmental Monitoring Quality Assurance Project Plan (HNF-EP-0538-4), and Hanford Analytical Services Quality Assurance Requirements Documents (DOE/RL-96-68). Should changes to this statement of work be necessary during CY 2000, WSCF or M\&R may amend it at any time with a jointly approved internal memo.

\subsection{REGULATORY REPORTING REQUIREMENTS}

For ECP to fulfill certain regulatory commitments, WSCF must meet the due dates specified in this document. The analytical data WSCF is to provide by these critical dates are essential for maintaining compliance with environmental release reporting deadlines mandated by federal and state regulatory agencies and the U.S. Department of Energy (DOE). Variances to technical criteria or due dates stipulated in this document must be documented by WSCF and approved or acknowledged by M\&R. The key reports are described in subsequent subsections. 
HNF-EP-0835-6

\subsection{RADIONUCLIDE AIR EMISSIONS REPORT FOR THE CLEAN AIR ACT}

This report documents radionuclide air emissions from the Hanford Site and the resulting effective dose equivalent to any member of the public from those emissions. This report complies with the reporting requirements of Title 40, Code of Federal Regulations, "Protection of the Environment," Part 61, "National Emissions Standards for Hazardous Air Pollutants," Subpart H, "National Emission Standards for Emissions of Radionuclides Other Than Radon from Department of Energy Facilities" (40 CFR 61 Subpart H) and Chapter 246-247 of the Washington Administrative Code (WAC 246-247).

\subsection{ENVIRONMENTAL RELEASES REPORT}

This report fulfills the effluent discharge reporting requirements of DOE Order 5400.1, "General Environmental Protection Program," and summarizes the compliance status of effluent releases from facilities managed under the Project Hanford Management Contract (PHMC), the River Protection Project (RPP), and the and Environmental Restoration Contract (ERC).

\subsection{HANFORD SITE ENVIRONMENTAL REPORT}

Pacific Northwest National Laboratory (PNNL) annually compiles and publishes this report for DOE, in compliance with DOE Order 5400.1. M\&R and EMI provide, respectively, the effluent and the near-facility monitoring sections of this report.

\subsection{EFFLUENT INFORMATION SYSTEM-ONSITE DISCHARGE INFORMATION SYSTEM REPORT}

For all Hanford contractors each year, ES compiles and transmits this report electronically to the Idaho National Engineering Laboratory in Idaho Falls for inclusion in the Effluent Information System-Onsite Discharge Information System (EIS-ODIS) database, in compliance with DOE Order 5400.1 .

\subsection{HANFORD SITE NEAR-FACILITY ENVIRONMENTAL MONITORING ANNUAL REPORT}

EMI annually publishes this data report as an appendix to the PNNL Hanford Site Environmental Report. It has a calendar-year summary of analysis results of samples collected of soil, vegetation, ambient air, and other media near Hanford facilities. This monitoring is performed in accordance with 40 CFR 61 Subpart H, WAC 246-247, DOE Order 5400.1, and DOE Order 5820.2A requirements. 
HNF-EP-0835-6

\subsection{WSCF SERVICES AND DATA QUALITY OBJECTIVES}

WSCF shall provide the following analytical services when analyzing low-level effluent and environmental samples.

\subsection{SAMPLE AND ANALYSIS REQUIREMENTS}

All services necessary shall be provided to complete the analytical requirements listed in Tables 1 through 4 . Analyses shall be performed in accordance with applicable requirements and procedures contained in the references listed in section 1.0 above. Analytical results shall be expressed in the units shown in the tables for the respective minimum detectable concentrations (MDCs).

\subsection{COMPOSITE SAMPLE REPORTING REQUIREMENTS}

Air emission (or effluent) samples designated as composite samples shall be composited quarterly or monthly, with all analysis results expressed in units of concentration. Results from the first three quarters shall be reported via ABCASH to M\&R by the following dates:

- first-quarter air emission composite sample results. June 30, 2000

- second-quarter air emission composite sample results ...... September 30, 2000

- third-quarter air emission composite sample results December 31, 2000

Ambient air (i.e., non-effluent) samples shall be combined into composite samples biannually and reported via $\mathrm{ABCASH}$ to EMI within 90 days of receiving all samples and the data needed to create the composite sample. All results shall be expressed in units of concentration, unless otherwise specified.

\subsection{YEAR-END DATA REPORTING DUE DATES}

The due date for WSCF to provide M\&R year-end analysis results for all air emission samples collected up through December 31 is February 24, 2001.

The due date for WSCF to provide EMI with year-end analysis results for all environmental (ambient air; surface water; and pond vegetation and sediment) samples collected up through December 31 is March 16, 2001.

All results shall be transmitted electronically and shall be expressed in units of concentration, unless otherwise specified. The analysis results from any weekly, biweekly, or monthly air samples collected on or after January 1 of the succeeding new year will be applied to that year. 
HNF-EP-0835-6

\subsection{LABORATORY PROCEDURES}

Use laboratory analytical procedures that are:

- in compliance with U.S. Environmental Protection Agency (EPA) Method 114, Section 4.0, "Quality Assurance Methods," as found in 40 CFR Part 61, Appendix B (specifically, 4.4 and 4.5), and other applicable requirements and procedures contained in the references listed in Section 1.0 above.

- in compliance with Chapter 6.0 of the Environmental Regulatory Guide for Radiological Effluent Monitoring and Environmental Surveillance document (DOE-EH-0173T).

- in compliance with the requirements specified in the Hanford Analytical Services Quality Assurance Requirements Documents (DOE/RL-96-68).

- appropriate to the sample medium and size as well as the analysis requirements listed in Tables 1 through 4

- newly developed for special needs, such as destructive analysis of HEPA filters, and whose analysis requirements and methods are agreed upon by all parties involved, including M\&R.

\subsection{QUALITY CONTROL}

WSCF shall assure the integrity and validity of analytical test results through implementation of an internal quality control program. Standard methods shall be used whenever possible. New methods that are developed or adapted shall be tested and completely documented.

WSCF shall perform calibration and quality control checks using methods consistent with the Hanford Analytical Services Quality Assurance Requirements Documents (DOE/RL-96-68). Biannually, WSCF shall provide data to $M \& R$ that demonstrate the data quality objectives for accuracy, precision, and completeness have been met. Auditable quality control (QC) test results shall be provided within two weeks of having received a request for specific records, without any additional charges. Other special data requests should be accommodated within two weeks of receiving each request. These special requests may necessitate additional resources, which could require further funding that the requestor is responsible to provide.

WSCF shall participate in the U.S. DOE Environmental Measurements Laboratory (EML) intercomparison program, as required by DOE/EH-0173T. WSCF shall also participate in EPA laboratory intercomparison programs, applicable to analyses it performs. EML and EPA laboratory intercomparison results shall be provided annually. 
HNF-EP-0835-6

\subsubsection{Water, Vegetation, and Soil Sample Analyses}

QC tests shall be for accuracy, precision, and completeness; all results shall be documented. Analytical problems identified through analysis of QC samples shall be promptly corrected. WSCF shall produce a minimum of $90 \%$ usable and valid data for all ECP-related samples analyzed. WSCF shall biannually provide data to M\&R that demonstrate whether or not the objectives for accuracy, precision, and completeness have been met.

WSCF shall prepare and analyze laboratory control standards (LCSs) as well as blank and duplicate samples to verify the accuracy and precision of all radiochemical methods. The total number of all QC samples shall be no less than $10 \%$ of all ordered sample analyses. The LCSs shall be included with each batch of samples processed and have, as possible, a matrix, volume, mass, and other relevant characteristics of the actual samples being analyzed. The LCSs shall have a range of activity from 5 times to no greater than 20 times the MDC values in Tables 1 through 4 .

Accuracy requirements shall be met when $95 \%$ of the LCS results fall within $\pm 25 \%$. Precision requirements shall be met when duplicate results fall within $\pm 30 \%$ relative percent difference for samples $\geq 5$ times the MDC values in Tables 1 through 4 or when the analytical uncertainty is $\leq 20 \%$.

\subsubsection{Air Sample Analyses}

The QC tests shall be for accuracy, precision, and completeness. The results of all QC tests shall be documented. Analytical problems identified through analysis of QC samples shall be promptly corrected. WSCF shall produce a minimum of $90 \%$ usable data for all ECP-related samples analyzed. WSCF shall biannually provide data to M\&R that demonstrate whether or not the objectives for accuracy, precision, and completeness have been met.

Accuracy requirements shall be met when $95 \%$ of the results from counting-instrument performance-check standards falls within $\pm 25 \%$. Precision of air sample data shall be evaluated by recounting a portion of the samples analyzed, since the creation of duplicate samples is not feasible for air samples. M\&R will identify the samples to be used for precision analysis on a quarterly basis. Of those samples whose analysis results are integral to calculated air emissions, $10 \%$ of them (approximately 70 samples normally) will be recounted to determine precision. Precision requirements shall be met when samples fall within $\pm 30 \%$-relative-percent difference for activities $\geq 5$ times the MDC values in Tables 1 through 3 or when the analytical uncertainty is $\leq 20 \%$.

The requirements of Section 3.5.1 apply to air sample analyses which involve radiochemical separations. The data quality objectives for air samples requiring radiochemical separations shall be met when the objectives in specified in Section 3.5.1 are met. 
HNF-EP-0835-6

\subsection{RETENTION OF AND ACCESS TO RAW DATA AND RESULTS}

All raw data and analytical results shall be retained by WSCF as quality assurance documents for a minimum period of 5 years, as specified by 40 CFR 61 Subpart $H$.

M\&R and EMI shall have access to all available raw data and results related to their samples. WSCF shall provide analysis printouts upon request. A list of GEA-identified peaks is an example of this type of printout.

\subsection{ANALYTICAL ERROR AND MINIMUM DETECTABLE CONCENTRATIONS}

WSCF shall provide the overall analytical error associated with each analytical result. Total analytical error shall be calculated at the $95 \%$-confidence interval.

WSCF shall ensure that the MDC for a sample of nominal volume does not exceed the values specified in Tables 1 through 4. WSCF will not be accountable for maintaining MDC limits when analyzing samples of less-than-nominal volumes. When sample sizes are less than or greater than the nominal volumes specified in Tables 1 through 3, M\&R may authorize WSCF to adjust the MDCs for samples by multiplying the specified MDC by the ratio of the actual sample size and the nominal sample size.

\subsection{ROUTINE ELECTRONIC TRANSFER OF ANALYTICAL DATA}

WSCF shall routinely have all analytical results available to M\&R and EMI via the ABCASH (Automated Bar Coding of Air Samples at Hanford) database. WSCF shall have downloaded to ABCASH all calendar year 2000 data for M\&R by February 24, 2001, and for EMI by March 16, 2001.

Owing to special analytical needs of the Spent Nuclear Fuels Project, total alpha and total beta results shall be available in ABCASH within 30 days of WSCF having received airborne effluent samples from the 105-KE and 105-KW Basins (i.e., EDP codes Y234, Y235, Y236, Y245, Y246, and Y248).

\subsection{ARCHIVING OF SAMPLES}

Ambient air samples in the Nxxx series of EDP codes shall be archived after total $\alpha$ and total $\beta$ analyses are completed. The archived ambient air samples shall then be combined into composite samples and analyzed biannually.

All calendar year 2000 air emission samples not destroyed as a necessity of chemicalseparation analysis for specific isotopes shall be archived at WSCF until October 1, 2001, after which they may be disposed of.

Backup record samples and continuous air monitor (CAM) samples of air emissions in calendar year 2000 shall not be analyzed (unless requested) but archived until October 1, 2001, 
HNF-EP-0835-6

after which they may be disposed of. These types of samples can be identified as those received in white envelopes stamped "Archive Only," having EDP codes not listed in the Appendix.

\subsection{ANALYSIS COSTS}

Costs for analyzing samples are shown in Tables 1 through 3. These prices contain additional fees associated with services specific to ECP, which are explained in Table 4 . These unit prices are effective through September 30,2000. Unit prices are evaluated each fiscal year and are subject to change. The analysis costs in Tables 1 through 3 are estimates that may fluctuate because of changes in work scope, material, and/or labor costs. Adjustments made to sample analysis costs must have the concurrence of $M \& R$.

\subsection{REFERENCES}

40 CFR 61 Subpart H, Code of Federal Regulations, Title 40, "Protection of the Environment," Part 61, "National Emissions Standards for Hazardous Air Pollutants," Subpart H, "National Emission Standards for Emissions of Radionuclides Other Than Radon From Department of Energy Facilities," as amended, U.S. Environmental Protection Agency, Washington, D.C.

40 CFR 61 Appendix B, Code of Federal Regulations, Title 40, "Protection of the Environment," Part 61, "National Emissions Standards for Hazardous Air Pollutants," Appendix B, "Quality Assurance Methods," as amended, Appendix B, U.S. Environmental Protection Agency, Washington, D.C.

ASTM, 1991, Establishing a Measurement System Quality Control Program for Analytical Chemistry Laboratories Within the Nuclear Industry, ASTM C 1210, American Society for Testing and Materials.

DOE, 1988a, General Environmental Protection Program, DOE Order 5400.1, U.S. Department of Energy, Washington, D.C.

DOE, 1988b, Radioactive Waste Management, DOE Order 5820.2A, U.S. Department of Energy, Washington, D.C. [Note: This order has been superseded by DOE Order 435.1, Radioactive Waste Management, but is still recognized as in effect at the Hanford Site because it is cited in current contractual documents.]

DOE, 1983, Environmental Protection, Safety and Health Protection Information Reporting Requirements, DOE Order 5484.1, U.S. Department of Energy, Washington D.C.

DOE, 1991, Environmental Regulatory Guide for Radiological Effluent Monitoring and Environmental Surveillance, DOE/EH-0173T, U.S. Department of Energy, Washington D.C. 
HNF-EP-0835-6

DOE, 1996, Hanford Analytical Services Quality Assurance Requirements Documents, DOE/RL-96-68, U.S. Department of Energy, Richland, Washington.

HPS, 1996, Performance Criteria for Radiobioassay, HPS N13.30, an American National Standard, Health Physics Society, McLean, Virginia.

WAC 246-247, Washington Administrative Code Chapter 246-247, "Radiation Protection - Air Emissions," as amended, Washington Department of Health, Olympia, Washington.

WHC, 1994, Quality Assurance Project Plan for Facility Effluent Monitoring Plan Activities, WHC-EP-0446-2, Westinghouse Hanford Company, Richland, Washington.

WMH, 1998, NESHAP Quality Assurance Project Plan for Radioactive Airborne Emissions, HNF-0528-3, Waste Management Federal Services of Hanford, Inc., Richland, Washington.

WMNW, 1999, Near-Facility Environmental Monitoring Quality Assurance Project Plan, HNF-EP-0538-4, Waste Management Federal Services, Inc. Northwest Operations, Richland, Washington. 


\section{Table 1. Air Emission and Ambient Air Sample Analysis Criteria for the Waste Sampling and Characterization Facility}

\begin{tabular}{|c|c|c|c|c|c|}
\hline $\begin{array}{l}\text { Nominal } \\
\text { sample volume }\end{array}$ & $\begin{array}{l}\text { Type of } \\
\text { andyis. }\end{array}$ & $\begin{array}{c}\mathrm{MDC}^{\mathbf{a}} \\
(\mu \mathrm{Clml})\end{array}$ & $\frac{\mathrm{MDA}^{\mathrm{b}}}{\left(\mu \mathrm{C}^{\prime}\right)}$ & $(\mathrm{dT}$ & walk \\
\hline \multirow{2}{*}{$\begin{array}{c}20,000 \mathrm{ft}^{3} \\
(5.66 \mathrm{E}+08 \mathrm{ml})\end{array}$} & $\begin{array}{l}\text { total } \alpha \text { and } \\
\text { total } \beta\end{array}$ & $\begin{array}{c}2.0 \mathrm{E}-15(\alpha) \text { and } \\
1.9 \mathrm{E}-14(\beta)\end{array}$ & $\begin{array}{c}1.1 \mathrm{E}-06(\alpha) \text { and } \\
1.1 \mathrm{E}-05(\beta)\end{array}$ & 14 & 176 \\
\hline & Ag zeolite & $\begin{array}{l}3.4 \mathrm{E}-13 \\
\text { (as }{ }^{106} \mathrm{Ru} \text { ) }\end{array}$ & $\begin{array}{c}1.9 \mathrm{E}-04 \\
\left.\text { (as }{ }^{106} \mathrm{Ru}\right)\end{array}$ & 30 & 249 \\
\hline \multirow{7}{*}{$\begin{array}{c}262,000 \mathrm{ft}^{3} \\
(7.42 \mathrm{E}+09 \mathrm{ml})\end{array}$} & ${ }^{90} \mathrm{Sr}$ & $1.9 \mathrm{E}-14$ & 1.4 E-04 & 90 & 402 \\
\hline & $\mathrm{GEA}^{\mathrm{d}}$ & $\begin{array}{l}1.9 \mathrm{E}-14 \\
\left(\text { as }{ }^{137} \mathrm{Cs}\right)\end{array}$ & $\begin{array}{l}1.4 \mathrm{E}-04 \\
\left(\text { as }{ }^{137} \mathrm{Cs}\right)\end{array}$ & 90 & 192 \\
\hline & $\begin{array}{c}\text { isotopic }{ }^{\mathrm{U}} \\
\left({ }^{234} \mathrm{U},{ }^{235} \mathrm{U},{ }^{238} \mathrm{U}\right)\end{array}$ & $7.1 \mathrm{E}-15$ & 5.3 E-05 & 90 & 471 \\
\hline & $\begin{array}{c}\text { isotopic } \mathrm{Pu} \\
\left({ }^{238} \mathrm{Pu},{ }^{239,240} \mathrm{Pu}\right)\end{array}$ & $2.0 \mathrm{E}-15$ & $1.5 \mathrm{E}-05$ & 90 & 376 \\
\hline & ${ }^{24 !} \mathrm{Pu}$ & $1.0 \mathrm{E}-13$ & 7.4 E-04 & 90 & 424 \\
\hline & ${ }^{241} \mathrm{Am}$ & $1.9 \mathrm{E}-15$ & $1.4 \mathrm{E}-05$ & 90 & 376 \\
\hline & $\begin{array}{c}\text { total } \alpha \\
\text { composite and } \\
\text { total } \beta \\
\text { composite }\end{array}$ & $\begin{array}{c}2.0 \mathrm{E}-15(\alpha) \text { and } \\
1.9 \mathrm{E}-14(\beta)\end{array}$ & $\begin{array}{c}1.5 \mathrm{E}-05(\alpha) \text { and } \\
1.4 \mathrm{E}-04(\beta)\end{array}$ & 90 & 177 \\
\hline $\begin{array}{c}22 \mathrm{ft}^{3} \\
(6.23 \mathrm{E}+05 \mathrm{ml})\end{array}$ & tritium $\left({ }^{3} \mathrm{H}\right)$ & $1.5 \mathrm{E}-09$ & 9.3 E-04 & 90 & 177 \\
\hline
\end{tabular}

$\mathrm{MDC}=$ minimum detectable concentration; $\mathrm{MDA}=$ minimum detectable activity; $\mathrm{TT}=$ turnaround time

aDCs shall be as low as reasonably attainable, and shall not exceed the values specified in the table. MDCs are the maximum allowed by the EPA, obtained from 40 CFR 61, Appendix E, Table II.

b MDAs shall be as low as reasonably achievable and shall not exceed the values specified in the table. They are derived by multiplying the MDC by the minimum sample volumes expected. A minimum sample volume of $20,000 \mathrm{ft}^{3}$ is expected for all total alpha and total beta analyses and $51,900 \mathrm{ft}^{3}$ for all isotopic analyses, with the exception of tritium. A minimum sample volume of $22 \mathrm{ft}^{3}$ is expected for tritium samples.

c These prices contain additional fees associated with services specific to ECP. Table 4 contains a detailed list of the additional services factored into unit prices.

${ }^{d}$ All positive GEA results shall be reported, with the exception of short-lived ${ }^{222} \mathrm{Rn}$ and ${ }^{220} \mathrm{Rn}$ progeny. 
Table 2. Groundwater Monitoring and Liquid Effluent Sample Analysis Criteria for the Waste Sampling and Characterization Facility ${ }^{a}$.

\begin{tabular}{|c|c|c|c|c|}
\hline Sample size & $\begin{array}{l}\text { Type of } \\
\text { analysis }\end{array}$ & $\begin{array}{c}\operatorname{MDC}^{\mathbf{b}} \\
(\mu \mathrm{Ci} / \mathrm{mL})^{\mathrm{c}}\end{array}$ & (days) & Unit price \\
\hline \multicolumn{5}{|c|}{ Radiological analyses } \\
\hline \multirow{7}{*}{$1.0 \mathrm{~L}$} & total $\alpha$ and total $\beta$ & $\begin{array}{c}1.2 \mathrm{E}-09(\alpha) \\
\text { and } \\
4.0 \mathrm{E}-08(\beta)\end{array}$ & 45 & 142 \\
\hline & ${ }^{3} \mathrm{H}$ & $8.0 \mathrm{E}-05$ & 45 & 142 \\
\hline & ${ }^{90} \mathrm{Sr}$ & $4,0 \mathrm{E}-08$ & 45 & 343 \\
\hline & $\mathrm{GEA}^{\mathrm{e}}$ & $\begin{array}{l}1.2 \mathrm{E}-07 \\
\left.\text { (as }{ }^{137} \mathrm{Cs}\right)\end{array}$ & 45 & 192 \\
\hline & $\begin{array}{c}\text { isotopic } U \\
\left({ }^{234} \mathrm{U},{ }^{233} \mathrm{U},{ }^{238} \mathrm{U}\right)\end{array}$ & $2.0 \mathrm{E}-08$ & 45 & 448 \\
\hline & $\begin{array}{c}\text { isotopic } \mathrm{Pu} \\
\left({ }^{238} \mathrm{Pu},{ }^{239 / 240} \mathrm{Pu}\right)\end{array}$ & $1.2 \mathrm{E}-09$ & 45 & 448 \\
\hline & ${ }^{241} \mathrm{Am}$ & $1.2 \mathrm{E}-09$ & 45 & 448 \\
\hline \multicolumn{5}{|c|}{ Nonradiological analyses } \\
\hline \multirow{2}{*}{$1.0 \mathrm{~L}$} & $\mathrm{pH}$ & NA & 60 & 36 \\
\hline & $\mathrm{NO}_{3}$ & $1.0 \mathrm{E}-06 \mathrm{~g} / \mathrm{mL}$ & 60 & 255 \\
\hline
\end{tabular}

$\mathrm{MDC}=$ minimum detectable concentration; $\mathrm{TT}=$ turnaround time.

a Liquid effluent samples shall be analyzed unfiltered, whereas groundwater samples shall be filtered and only the filtrate analyzed.

b MDCs shall be as low as reasonably attainable, but shall not exceed the values specified in the table. MDC values obtained from $4 \%$ of the Derived Concentration Guidelines (DCG).

${ }^{c}$ Unless other units of measure are indicated.

d These prices contain additional fees associated with services specific to the Environmental Compliance Program. Table 4 contains a detailed list of the additional services factored into unit prices.

${ }^{e}$ All positive GEA results shall be reported, with the exception of the short-lived ${ }^{222} \mathrm{Rn}$ and ${ }^{220} \mathrm{Rn}$ progeny. 
Table 3. Vegetation and Soil Sample Analysis Criteria for the Waste Sampling and Characterization Facility.

\begin{tabular}{|c|c|c|c|c|}
\hline Somploxtere & $\begin{array}{c}\text { Trype of } \\
\text { analysis }\end{array}$ & $\mathrm{MDC}^{2}$ & (dops) & Wath prot \\
\hline \multicolumn{5}{|c|}{ Radiological Analyses } \\
\hline \multirow{7}{*}{$500 \mathrm{~g}$ (dry wt) } & ${ }^{90} \mathrm{Sr}$ & $1.0 \mathrm{pCi} / \mathrm{g}$ & 45 & 382 \\
\hline & $\mathrm{GEA}^{\mathrm{b}}$ & $\begin{array}{l}0.20 \mathrm{pCi} / \mathrm{g} \\
\left.\text { (as }{ }^{137} \mathrm{Cs}\right)\end{array}$ & 45 & 205 \\
\hline & $\begin{array}{c}\text { Isotopic U } \\
\left({ }^{234} \mathrm{U},{ }^{235} \mathrm{U},{ }^{238} \mathrm{U}\right)\end{array}$ & $0.040 \mathrm{pCi} / \mathrm{g}$ & 45 & 486 \\
\hline & $\begin{array}{c}\text { Isotopic } \mathrm{Pu} \\
\left({ }^{238} \mathrm{Pu},{ }^{239 / 240} \mathrm{Pu}\right)\end{array}$ & $1.0 \mathrm{pCi} / \mathrm{g}$ & 45 & 486 \\
\hline & ${ }^{241} \mathrm{Pu}$ & $1.0 \mathrm{pCi} / \mathrm{g}$ & 45 & 425 \\
\hline & ${ }^{241} \mathrm{Am}$ & $1.0 \mathrm{pCi} / \mathrm{g}$ & 45 & $486^{c}$ \\
\hline & ${ }^{244} \mathrm{Cm}$ & $1.0 \mathrm{pCi} / \mathrm{g}$ & 45 & $486^{\mathrm{c}}$ \\
\hline \multicolumn{5}{|c|}{ Nonradiological Analyses } \\
\hline NA & $\mathrm{pH}$ & $\mathrm{NA}$ & 45 & 36 \\
\hline \multirow{4}{*}{$200 \mathrm{~g}$} & anions & $1.0 \mathrm{ppm}$ & 45 & 255 \\
\hline & $\begin{array}{c}\text { metals } \\
\text { EPA Method } 200.8^{\mathrm{d}}\end{array}$ & $1.0 \mathrm{ppm}$ & 45 & 249 \\
\hline & cyanide & $1.0 \mathrm{ppm}$ & 45 & 170 \\
\hline & PCBs & & 45 & 361 \\
\hline
\end{tabular}

$\mathrm{MDC}=$ minimum detectable limit; $\mathrm{g}=$ grams; $\mathrm{pCi} / \mathrm{g}=$ picocuries per gram; $\mathrm{ppm}=$ part per million; $\mathrm{EPA}=$ U.S. Environmental Protection Agency; $\mathrm{PCB}=$ polychlorinated biphenyls; $\mathrm{TT}=$ turnaround time; $\mathrm{NA}=$ not applicable; $\mathrm{pH}=$ potential of hydrogen.

a 30-day turnaround times are available for a higher price; for most sample analyses, the prices for 30-day turn-around times are approximately 1.5 times the 45 -day turnaround prices.

b All positive GEA results shall be reported, with the exception of short-lived ${ }^{222} \mathrm{Rn}$ and ${ }^{220} \mathrm{Rn}$ progeny.

c When ${ }^{241} \mathrm{Am}$ and ${ }^{244} \mathrm{Cm}$ are analyzed together, the combined price is $\$ 486$.

d The minimum list of metals for EPA Method 200.8 shall include $\mathrm{Ag}, \mathrm{Al}, \mathrm{As}, \mathrm{B}, \mathrm{Ba}, \mathrm{Be}, \mathrm{Ca}, \mathrm{Cd}, \mathrm{Co}, \mathrm{Cr}$,

$\mathrm{Cu}, \mathrm{Fe}, \mathrm{K}, \mathrm{Li}, \mathrm{Mg}, \mathrm{Mn}, \mathrm{Na}, \mathrm{Ni}, \mathrm{P}, \mathrm{Pb}, \mathrm{Sc}, \mathrm{Se}, \mathrm{Si}, \mathrm{Sb}, \mathrm{Sr}, \mathrm{Th}, \mathrm{Ti}, \mathrm{U}, \mathrm{V}, \mathrm{Y}, \mathrm{Zn}$, and $\mathrm{Zr}$. 
Table 4. Additional Services Factored into the Waste Sampling and Characterization Facility Sample Analysis Prices for the Environmental Compliance Program.

\begin{tabular}{|c|c|}
\hline $\begin{array}{l}\text { Sample } \\
\text { category }\end{array}$ & $\begin{array}{l}\text { Additional } \\
\text { services provided }\end{array}$ \\
\hline \multirow{10}{*}{$\begin{array}{l}\text { Air } \\
\text { samples }\end{array}$} & $\begin{array}{l}\text { Entering sample collection data into } \mathrm{ABCASH} \text {, for facilities not equipped with } \\
\text { barcoding equipment. }\end{array}$ \\
\hline & Downloading all air sample results into ABCASH. \\
\hline & Disposal of samples and wastes from chemical processing. \\
\hline & $\begin{array}{l}\text { Archiving near-field monitoring samples and effluent samples from major } \\
\text { emission units that require composite analyses. }\end{array}$ \\
\hline & Archiving samples from minor emission units that require quarterly analysis. \\
\hline & $\begin{array}{l}\text { Archiving effluent samples and backup effluent samples from minor emission } \\
\text { units that do not get analyzed. }\end{array}$ \\
\hline & $\begin{array}{l}\text { Notifying effluent and environmental monitoring points of contact }(\overline{\mathrm{POC}}) \text { about } \\
\text { zero ABCASH results. }\end{array}$ \\
\hline & $\begin{array}{l}\text { Sorting effluent samples into two groups: 1) samples to be analyzed and } \\
\text { 2) samples to be archived. }\end{array}$ \\
\hline & Assembly and preparation of samples for composite analysis. \\
\hline & $\begin{array}{l}\text { Preparation and analysis of quality-control (QC) samples (e.g., control standards, } \\
\text { blanks, duplicates, matrix spikes, etc.). }\end{array}$ \\
\hline \multirow{5}{*}{$\begin{array}{l}\text { Liquid } \\
\text { samples }\end{array}$} & Archiving samples until composite analysis is performed. \\
\hline & $\begin{array}{l}\text { Archiving unused samples until Environmental Compliance Program (ECP) } \\
\text { reports are issued. }\end{array}$ \\
\hline & $\begin{array}{l}\text { Assembly and preparation of samples for composite analysis, which includes } \\
\text { verifying receipt of all samples for composite, calculating effluent stream } \\
\text { volumes, and determining aliquot sizes for composite. }\end{array}$ \\
\hline & Disposal of samples and wastes from chemical processing. \\
\hline & $\begin{array}{l}\text { Preparation and analysis of QC samples (e.g., control standards, blanks, } \\
\text { duplicates, matrix spikes, etc.). }\end{array}$ \\
\hline \multirow{4}{*}{ Miscellaneous } & Supporting audits of the ECP. \\
\hline & Participate in prescribed laboratory intercomparison programs. \\
\hline & $\begin{array}{l}\text { Provide laboratory intercomparison results to Fluor Hanford Monitoring \& } \\
\text { Reporting. }\end{array}$ \\
\hline & Perform rush and emergency sample analyses. \\
\hline
\end{tabular}




\section{GLOSSARY}

\section{ABBREVIATIONS AND ACRONYMS}

$\begin{array}{ll}\text { ABCASH } & \text { Automated Bar Coding of Air Samples at Hanford } \\ \text { CAM } & \text { continuous air monitor } \\ \text { DOE } & \text { U.S. Department of Energy } \\ \text { DOE-RL } & \text { U.S. Department of Energy, Richland Operations } \\ \text { ECP } & \text { Environmental Compliance Program } \\ \text { EDP code } & \text { Electronic Data Processing code } \\ \text { EIS-ODIS } & \text { Effluent Information System-Onsite Discharge Information System } \\ \text { EMI } & \text { Waste Management Technical Services Environmental Monitoring } \\ & \text { \& Investigations Organization } \\ \text { EML } & \text { Environmental Measurements Laboratory } \\ \text { EPA } & \text { U.S. Environmental Protection Agency } \\ \text { ES } & \text { Environmental Services } \\ \text { FH } & \text { Fluor Hanford } \\ \text { GEA } & \text { gamma energy analysis } \\ \text { LCS } & \text { laboratory control standards } \\ \text { MDA } & \text { minimum detectable activity } \\ \text { MDC } & \text { minimum detectable concentration } \\ \text { M\&R } & \text { Monitoring \& Reporting } \\ \text { NFM } & \text { near-facility monitoring } \\ \text { PHMC } & \text { Project Hanford Management Contractor } \\ \text { TT } & \text { turnaround time } \\ \text { TBD } & \text { to be determined } \\ \text { WAC } & \text { Washington Administrative Code } \\ \text { WMTS } & \text { Waste Management Technical Services } \\ \text { WSCF } & \text { Waste Sampling and Characterization Facility }\end{array}$

\section{DEFINITION OF TERMS}

Accuracy The degree of agreement a measurement has with a true or known value.

Completeness A measure of the amount of valid and usable data obtained from a measurement system compared to that expected under correct normal conditions.

Precision A measure of mutual agreement among individual measurements of the same property under similar conditions. Precision is best expressed in terms of standard deviation.

Turnaround time Elapsed time, in days, starting from the receipt at the laboratory of samples to be analyzed and all relevant sampling information and ending when the results, in units of concentration, are electronically accessible. 
HNF-EP-0835-6

This page intentionally left blank. 
HNF-EP-0835-6

ATTACHMENT

\begin{abstract}
ANALYTICAL REQUIREMENTS
FOR

ENVIRONMENTAL COMPLIANCE PROGRAM SAMPLES

DURING CY 2000
\end{abstract}

APP-1 


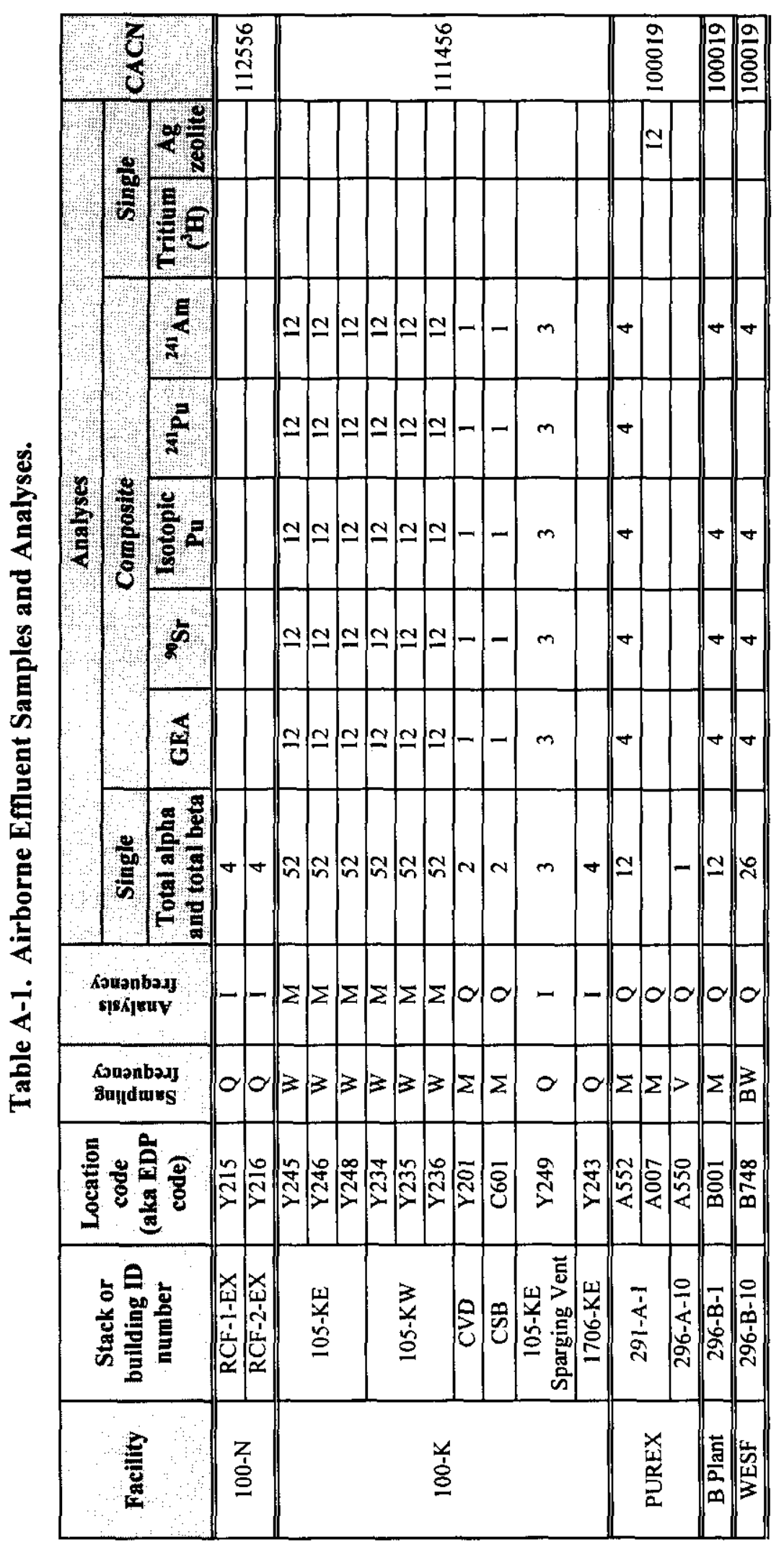




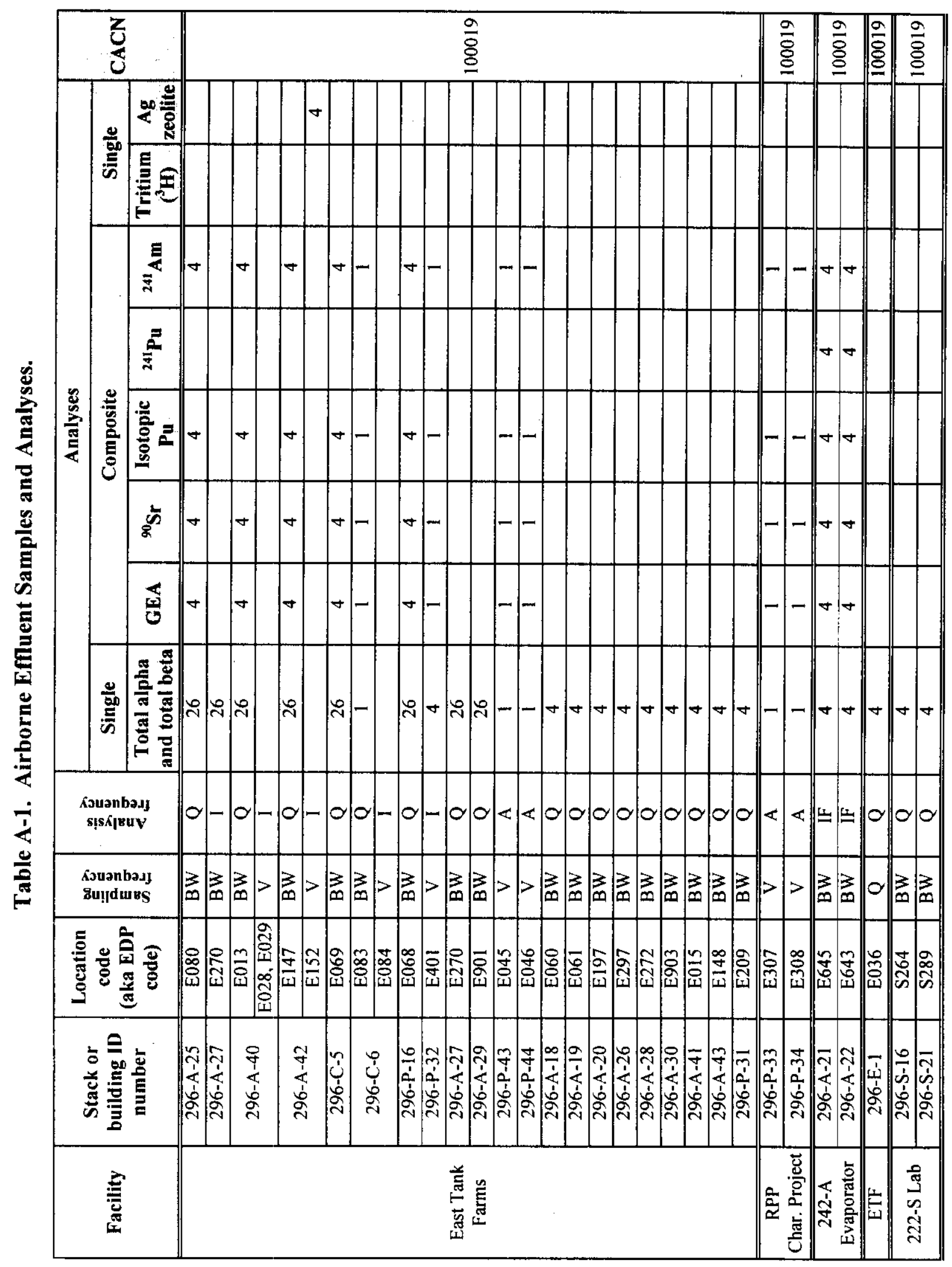




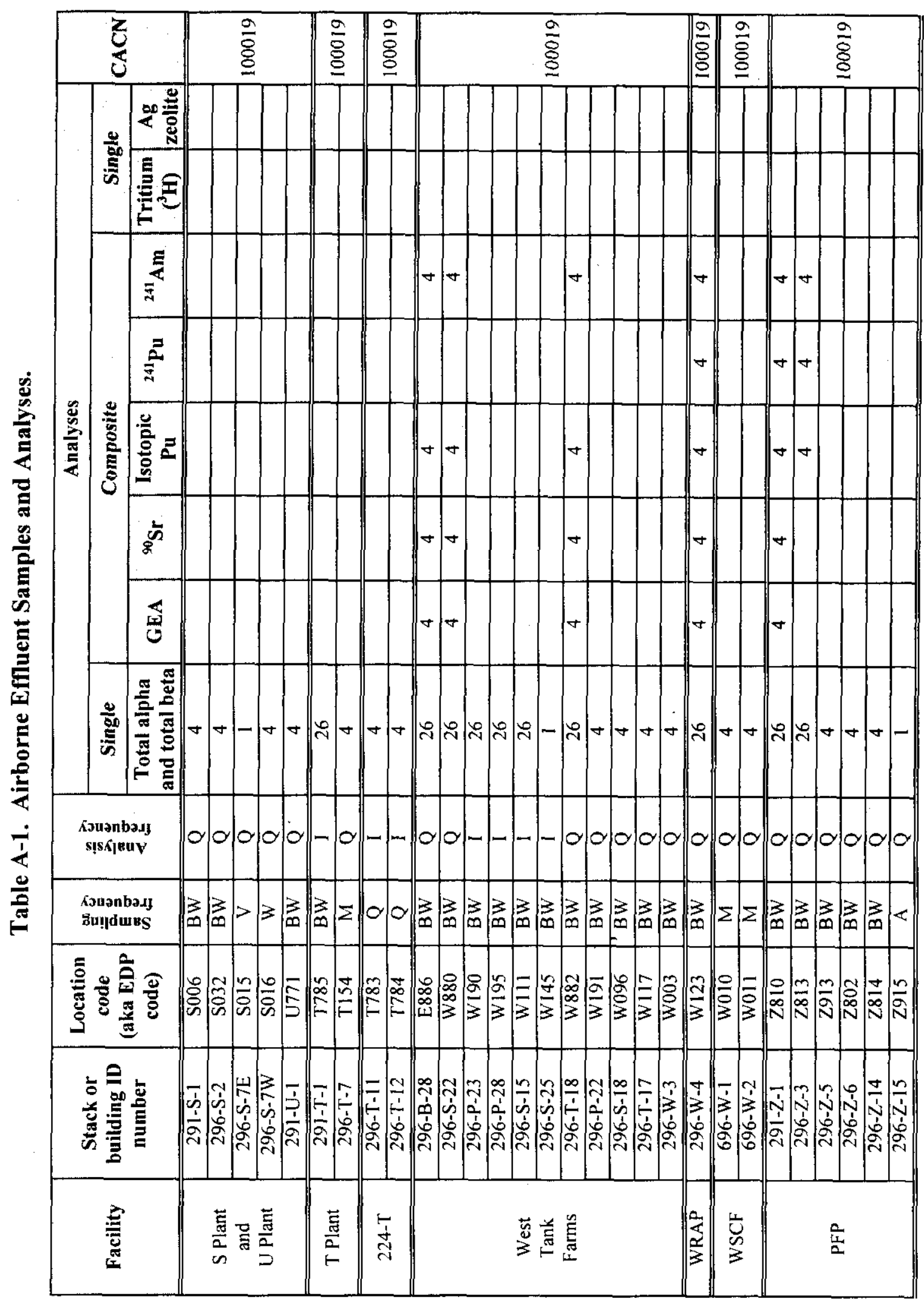




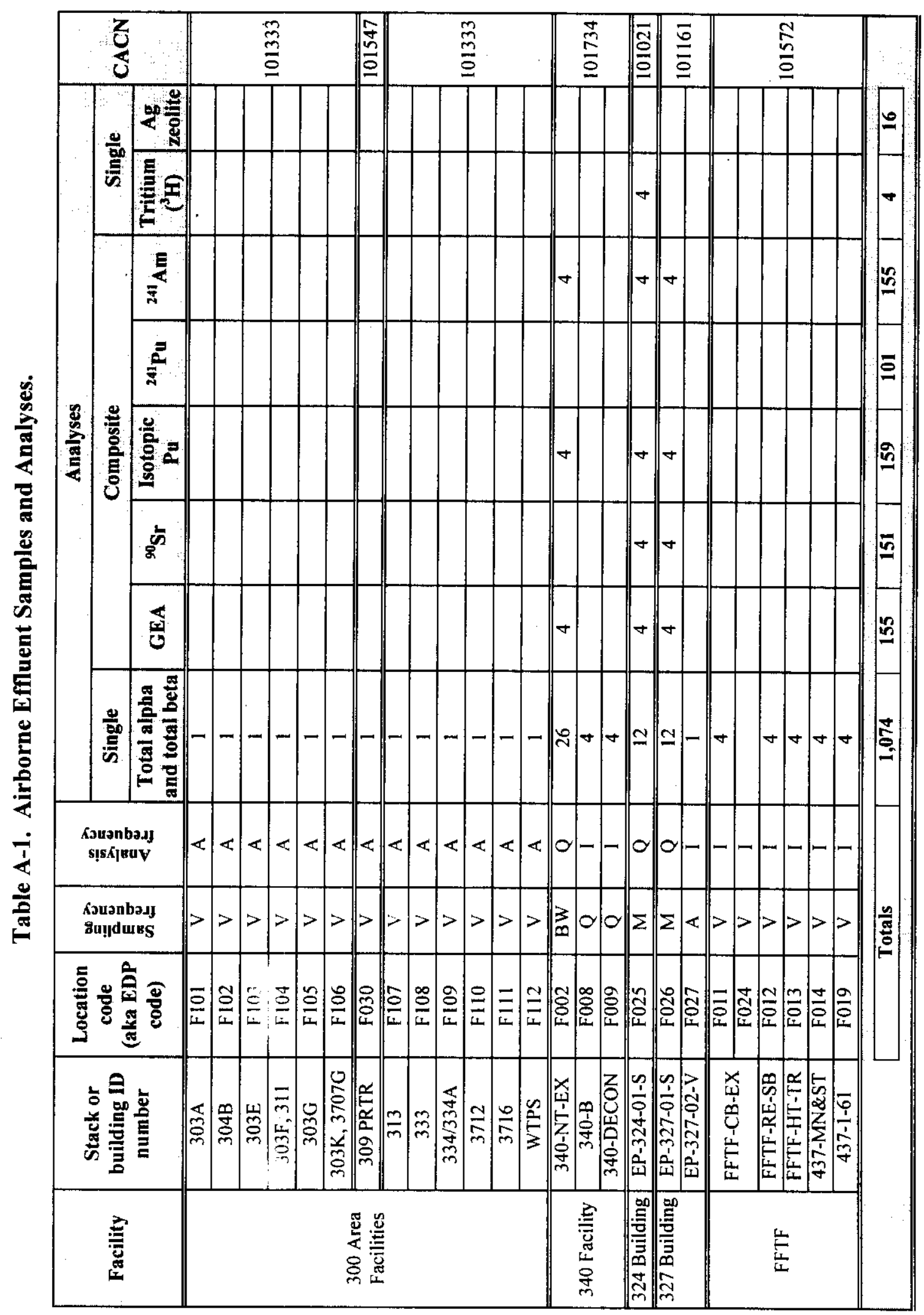



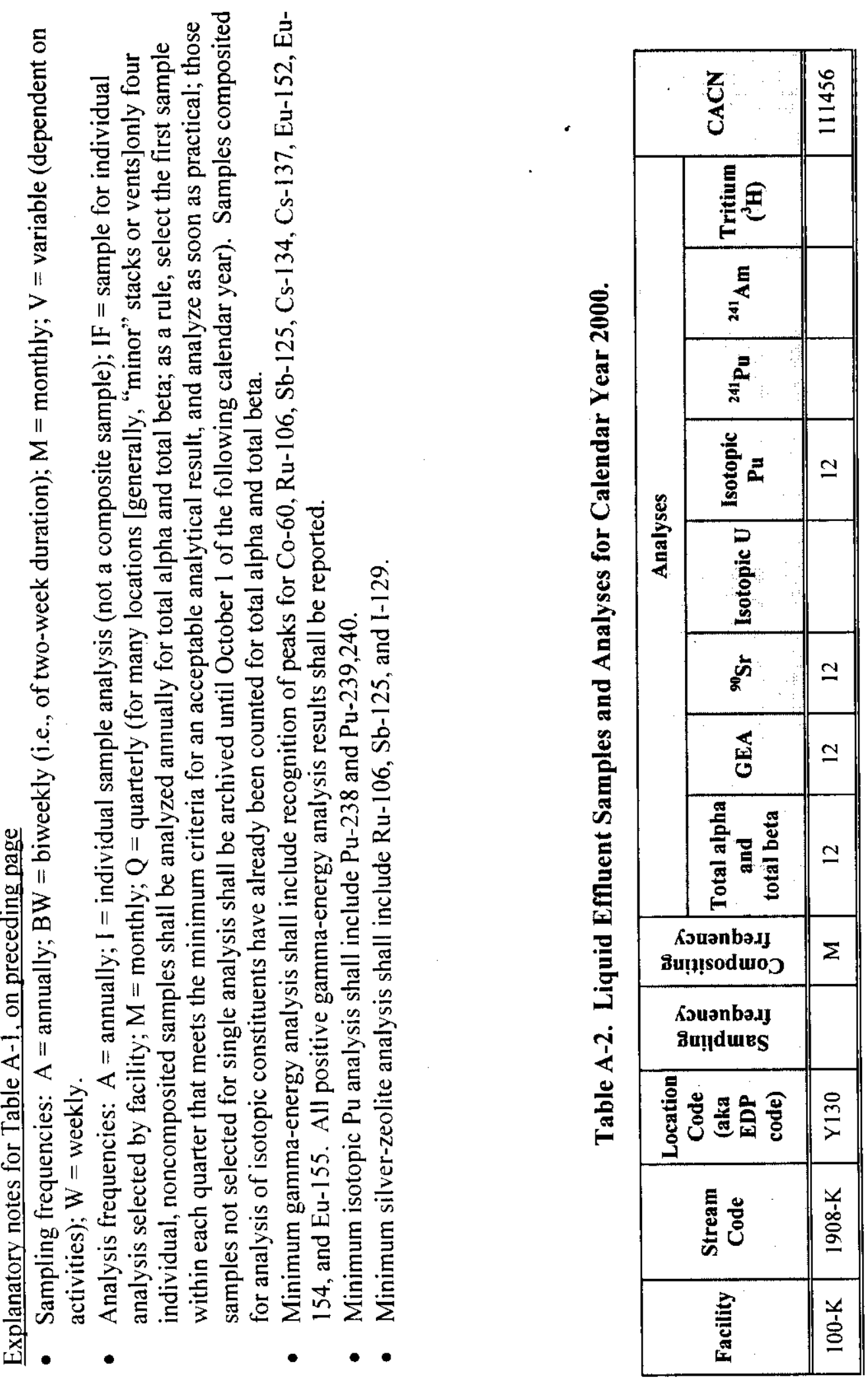


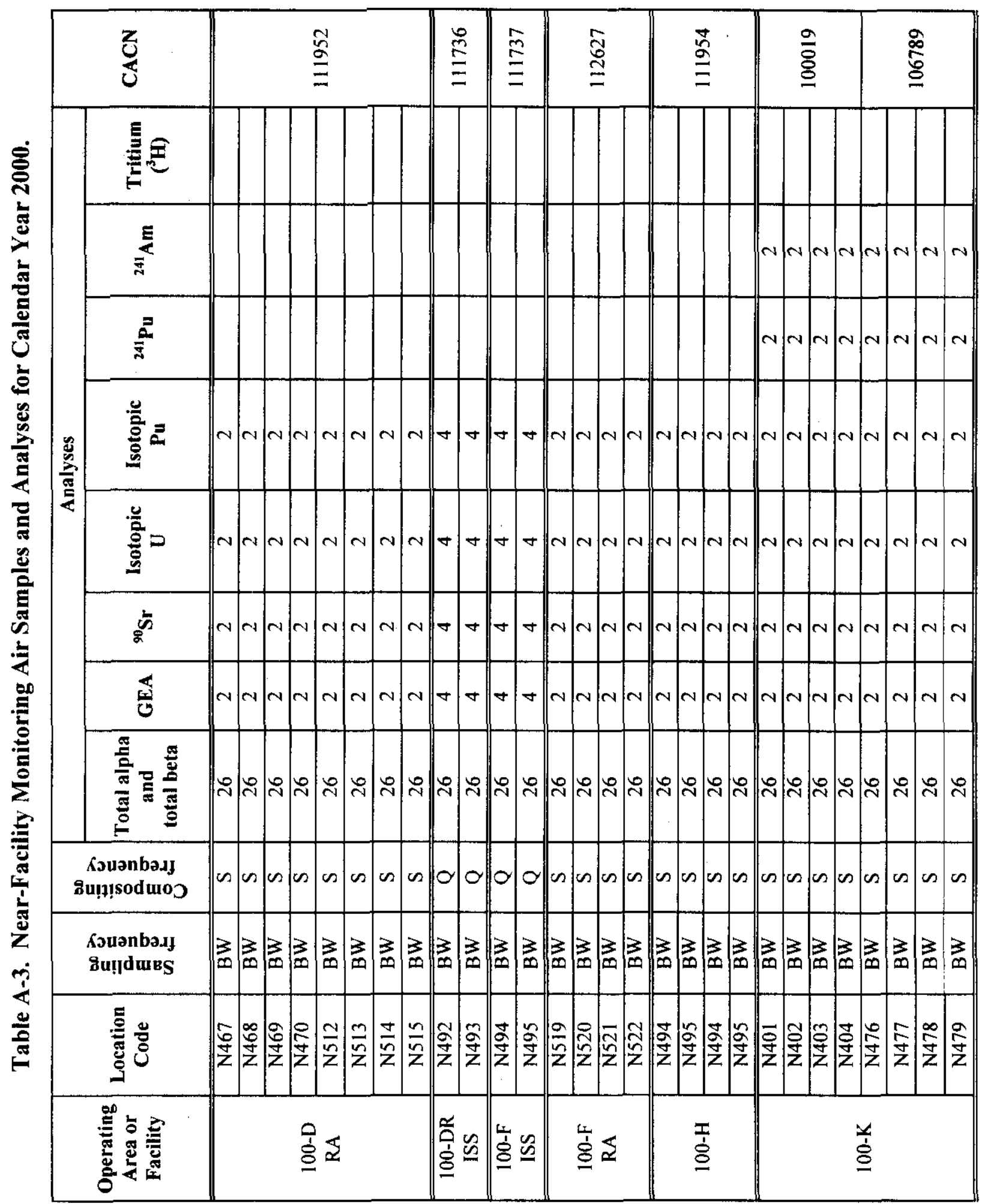


HNF-EP-0835-6

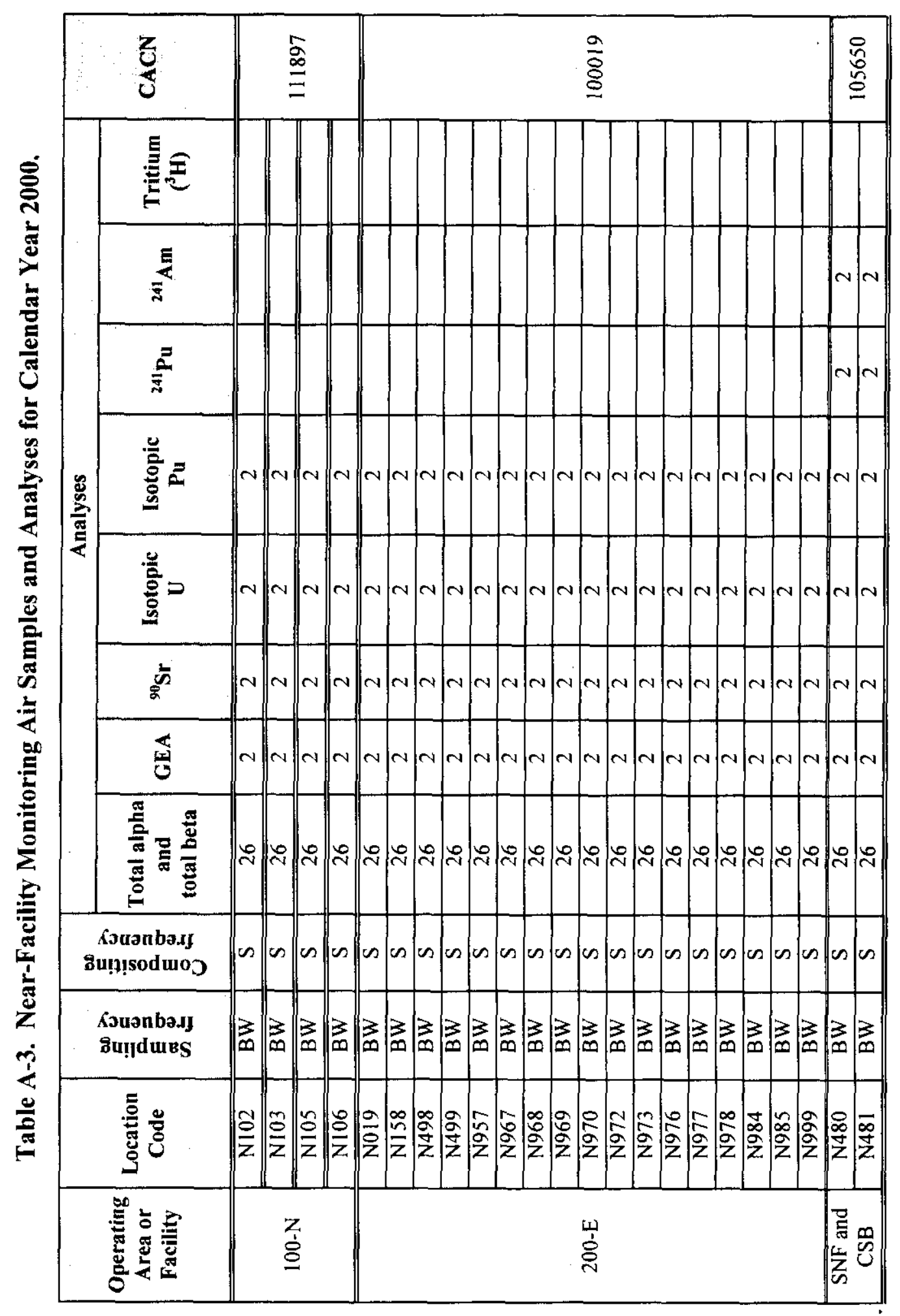




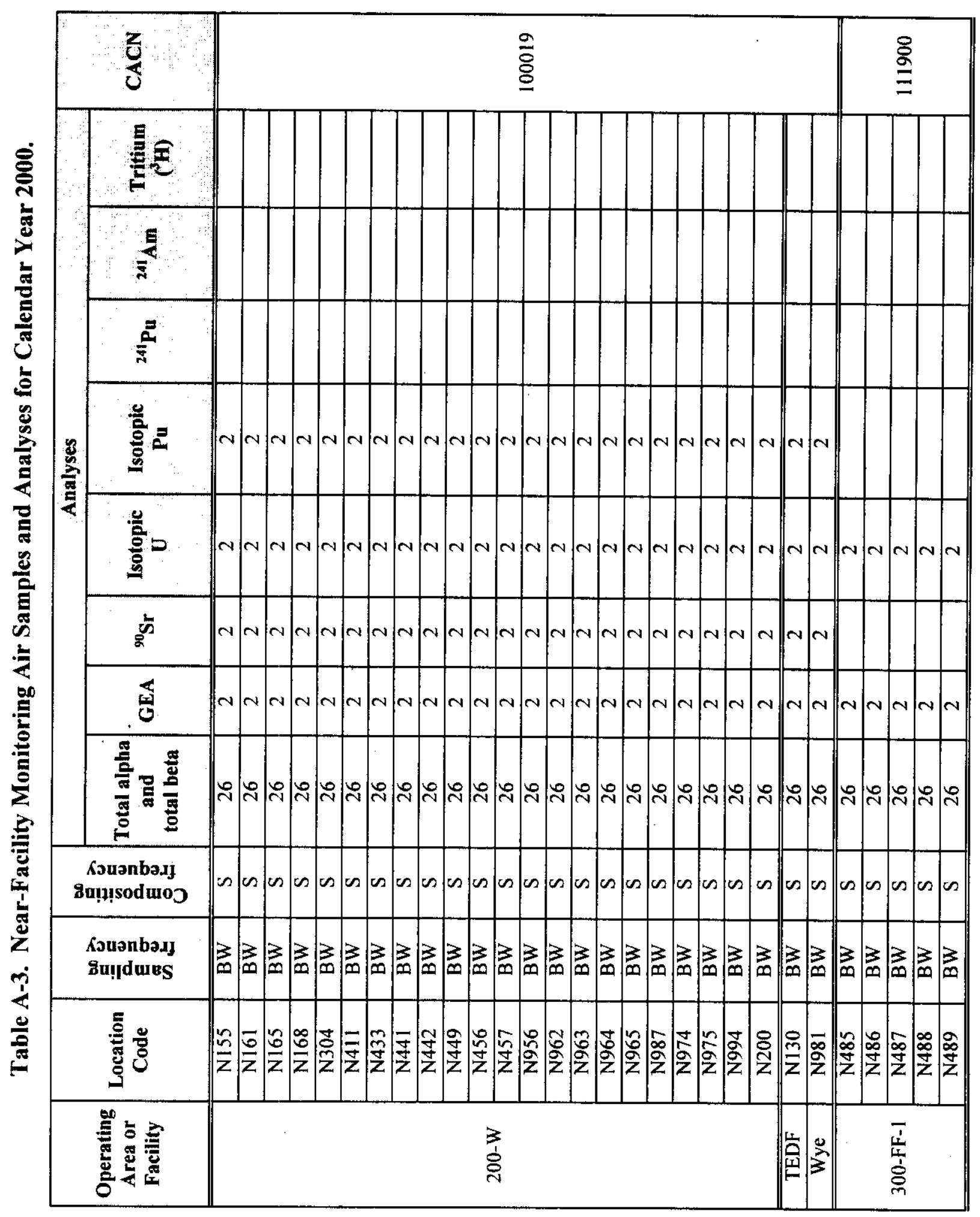


HNF-EP-0835-6

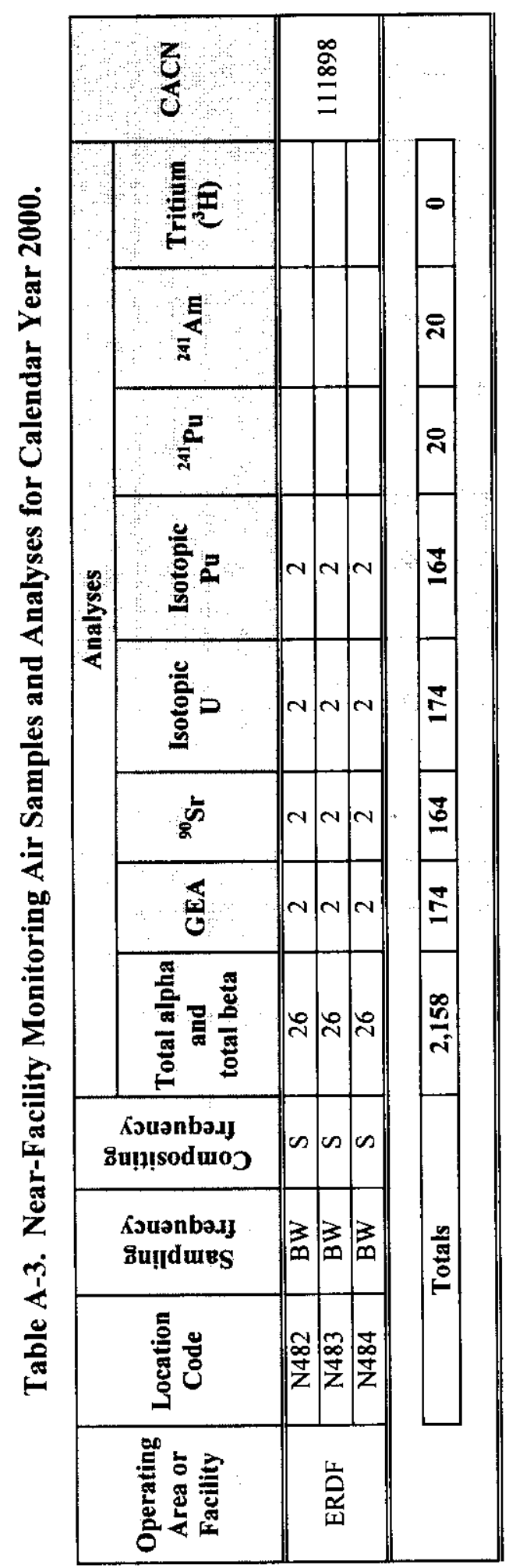




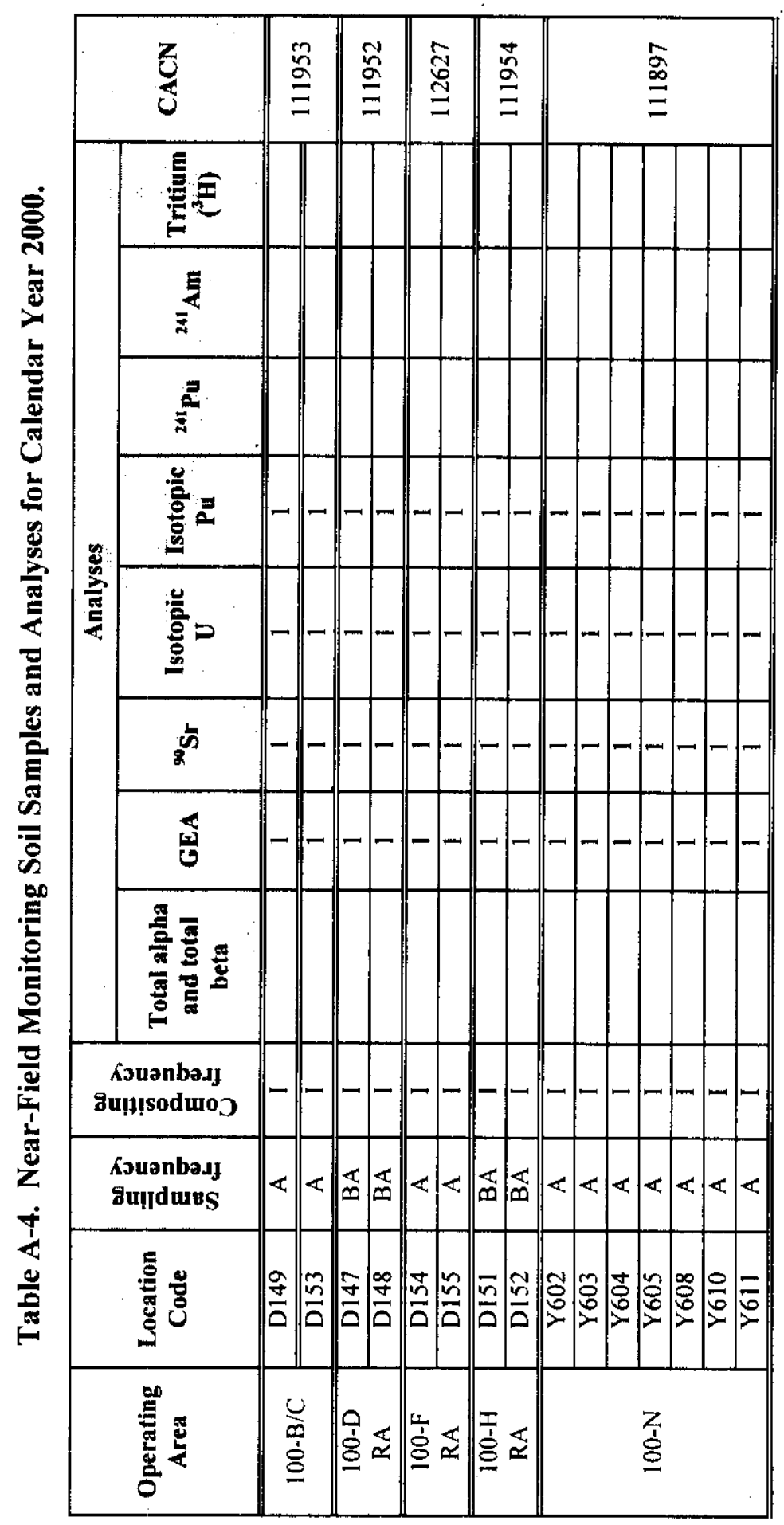




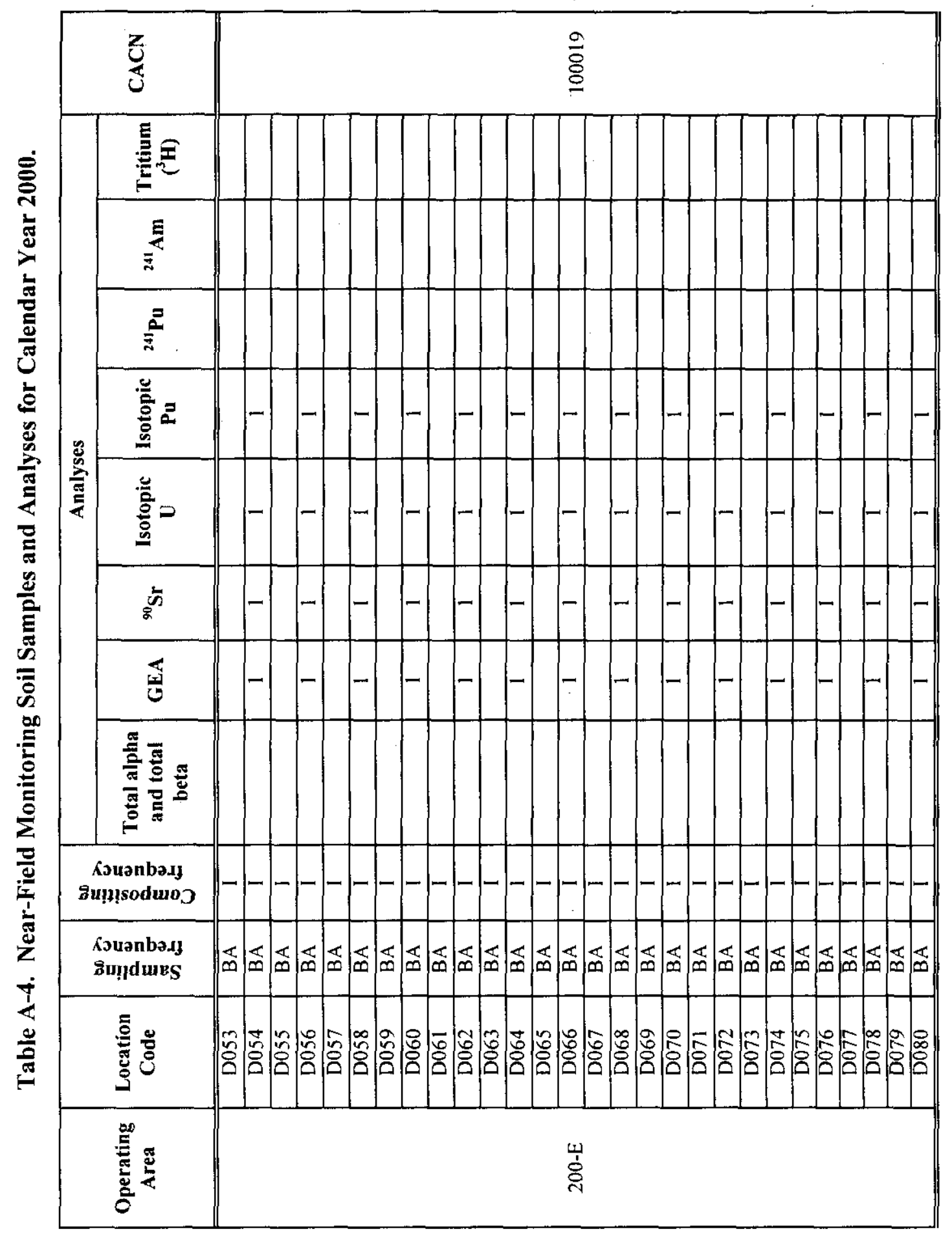




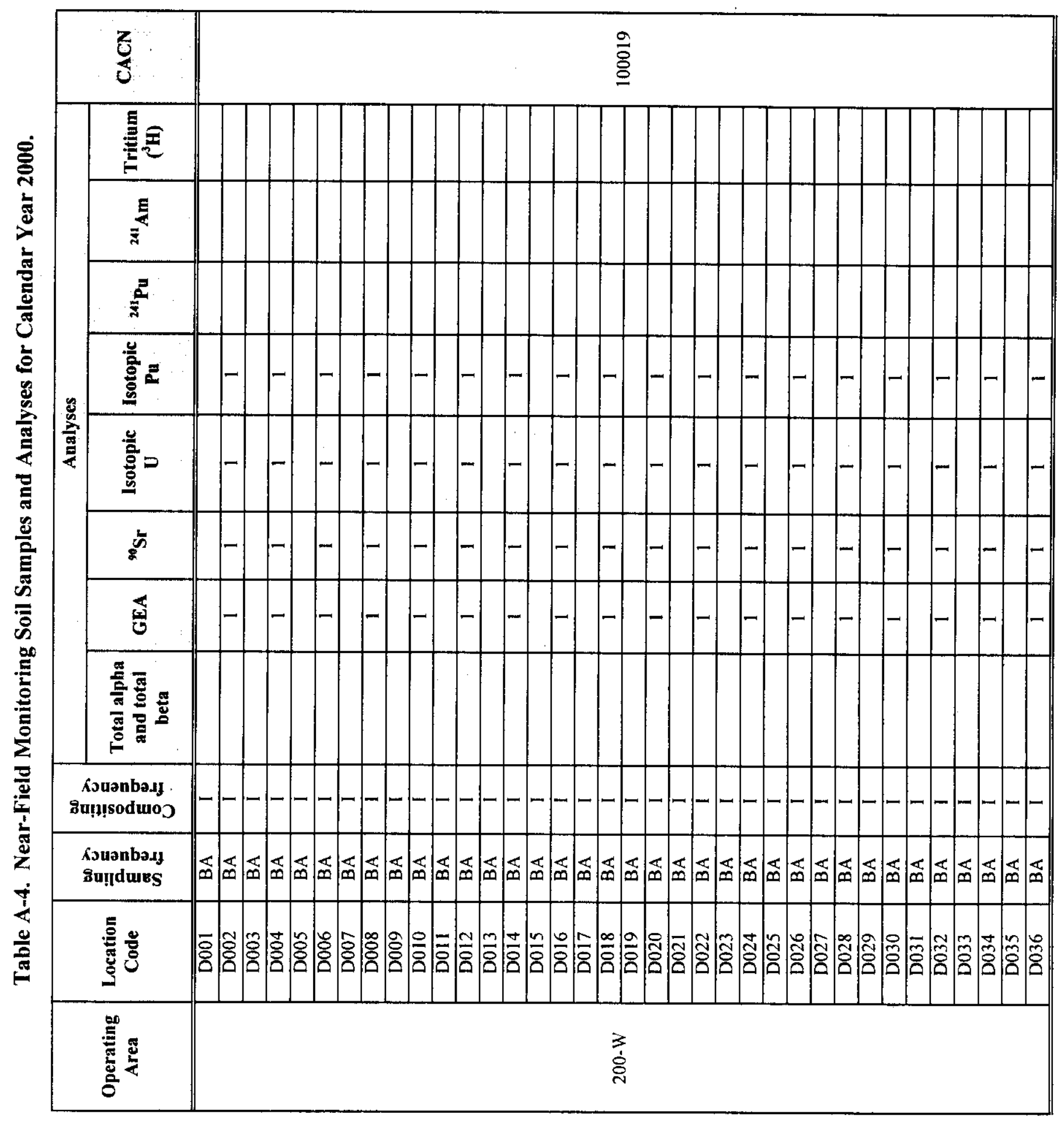




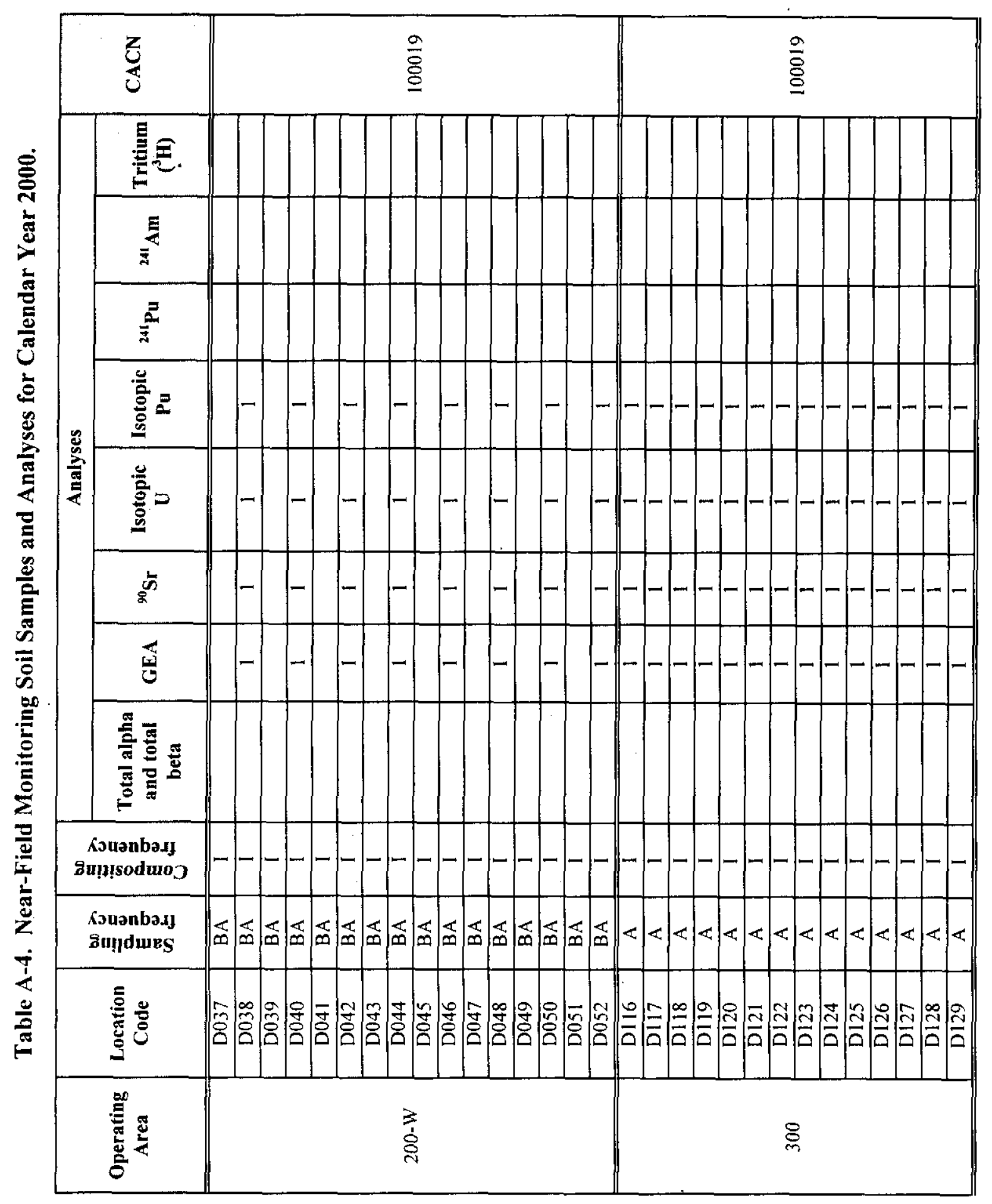




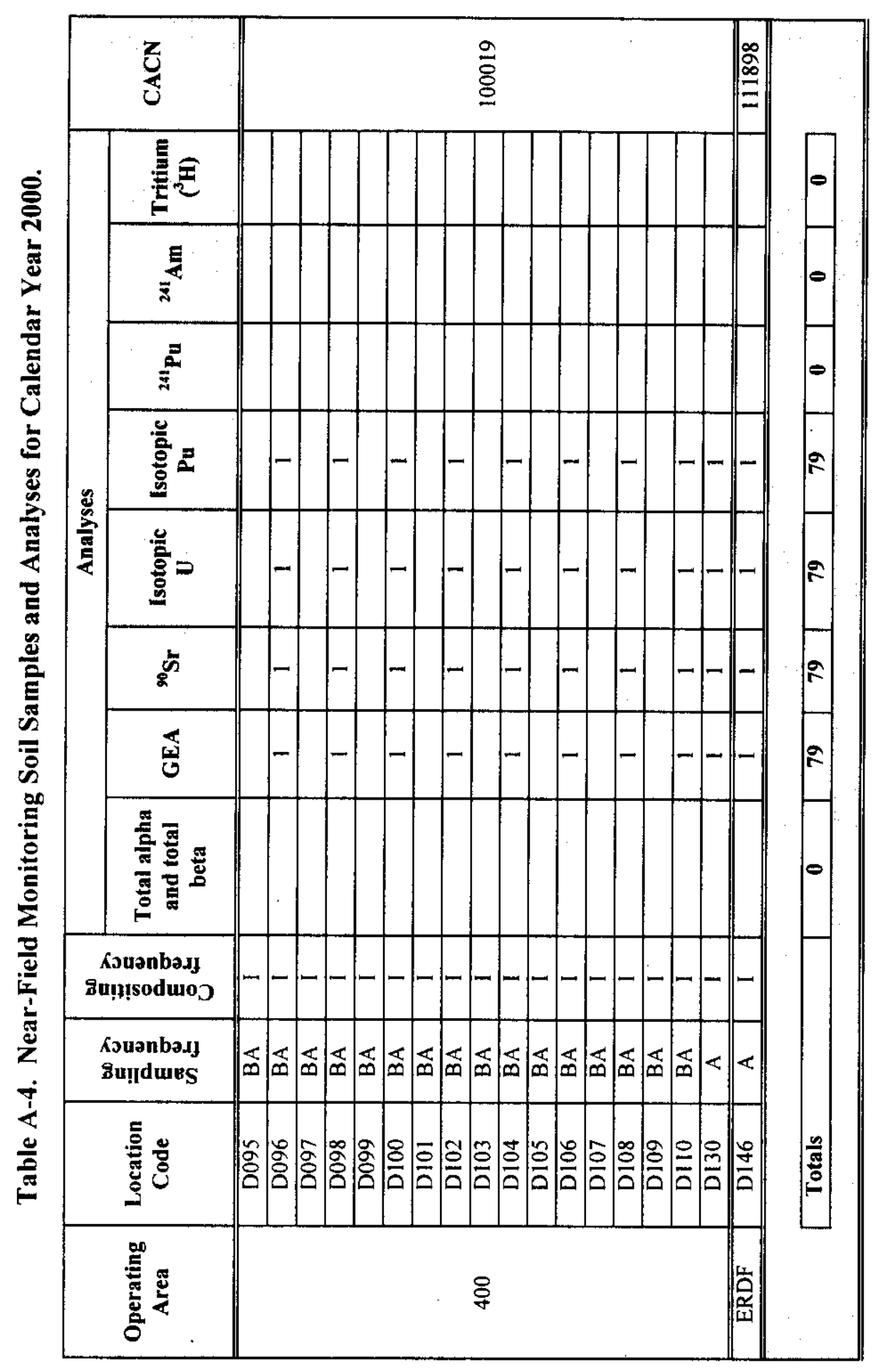




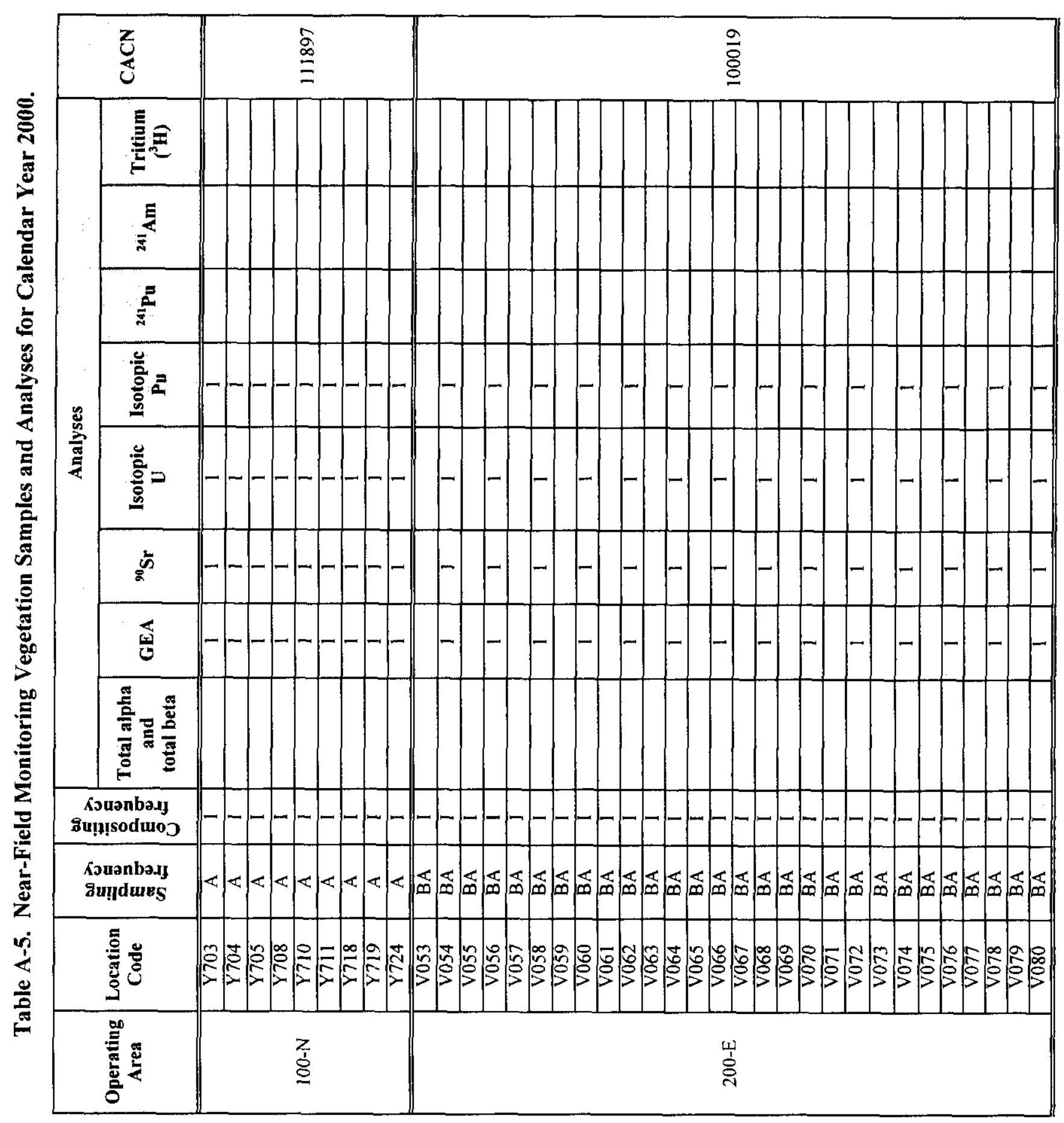


HNF-EP-0835-6

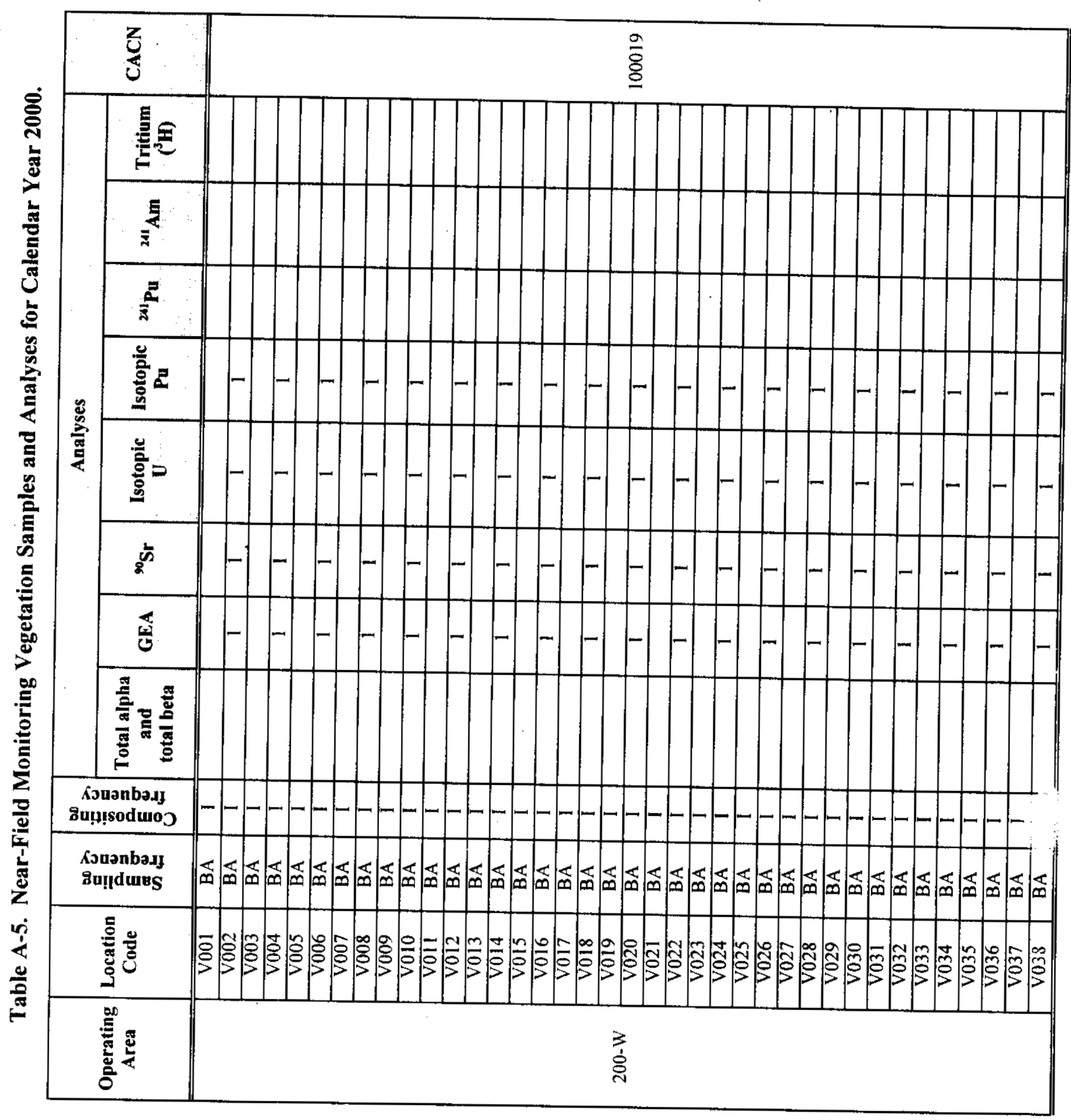




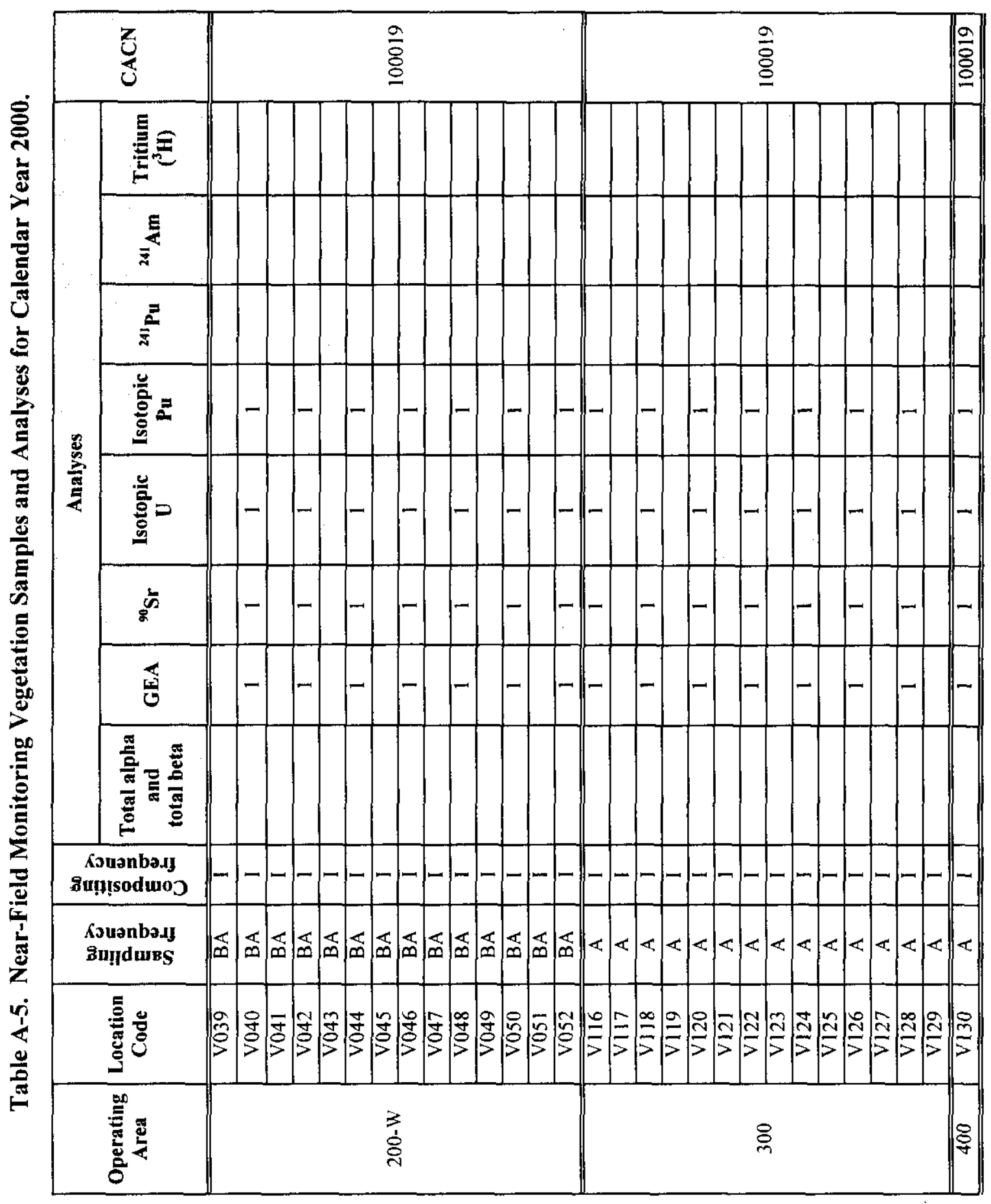




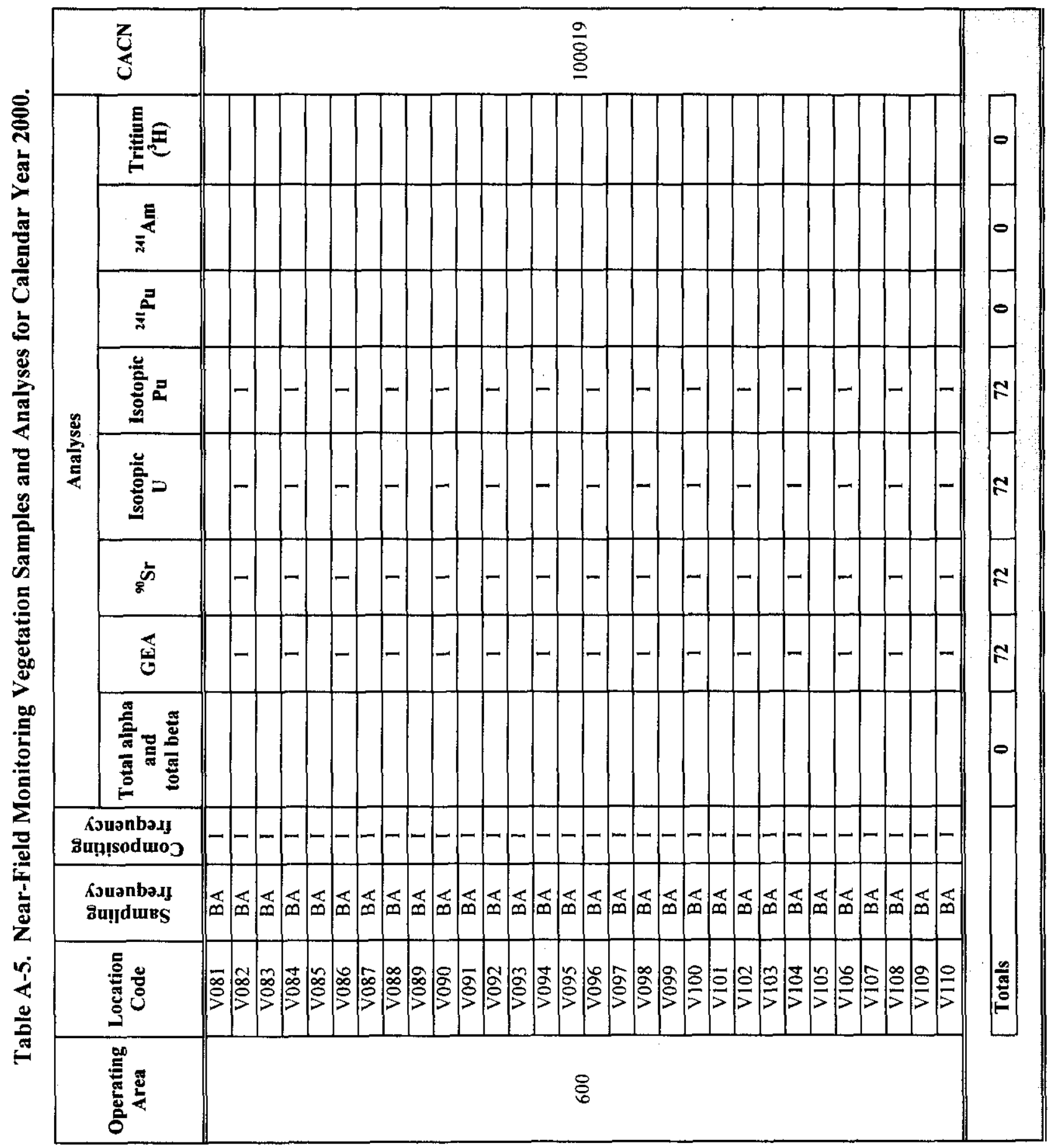


HNF-EP-0835-6

This page intentionally left blank. 
HNF-EP-0835-6

\section{DISTRIBUTION}

\section{Number of copies}

\section{ONSITE}

5

U.S. Department of Energy-

Richland Operations Office

C. R. Briggs

A1-61

J. B. Hall

A5-15

P. J. Krupin

A2-15

D. C. Ward

A2-15

Public Reading Room

5 Bechtel Hanford, Inc.

R. J. Landon

H0-02

D. W. Long

T7-05

J. E. Rugg

J. G. Woolard

S3-21

J. P. Zoric

H0-17

$\times 5-53$

1 CH2M HILL Hanford Group, Inc.

G. M. Crummel

R1-51

$49 \quad$ Fluor Hanford

J. M. Barnett

L1-05

N. R. Dahl

N2-57

A. K. Dasgupta (5)

S3-28

L. P. Diediker (10)

G1-29

S. L. Fitzgerald

S3-30

K. J. Greenough (5)

S3-30

R. G. Gant

X3-79

J. W. Hales

A1-14

G. S. Hunacek, Jr.

X3-79

D. L. Johnson

L1-05

R. E. Johnson

H6-25

T. W. Noland

H8-67

K. N. Pool

T6-03

K. L. Powell

S3-30

D. J. Rokkan (15)

G1-29

R. A. Spohr

T3-02

D. J. Watson

X3-79 


\section{DISTRIBUTION (continued)}

1 Lockheed Martin Services, Inc.

J. N. Diven H8-41

1 SGN Eurisys Services Corporation

$\begin{array}{ll}\text { J. D. Criddle } & \text { S7-12 }\end{array}$

6 Waste Management Technical Services, Inc.

J. J. Dorian

$\mathrm{H} 1-11$

A. R. Johnson

H5-26

B. M. Markes

H1- 11

S. M. McKinney

H1 11

R. M. Mitchell

H1-11

C. J. Perkins

H1-11

1

Central Files

B1-07

1

DPC

A3-94

Hanford Tech. Lib.

P\&-55 